\title{
Microglial Function and Regulation during Development, Homeostasis and Alzheimer's Disease
}

\author{
Brad T. Casali and Erin G. Reed-Geaghan *(D) \\ Department of Pharmaceutical Sciences, Northeast Ohio Medical University, Rootstown, OH 44272, USA; \\ bcasali@neomed.edu \\ * Correspondence: ereedgeaghan@neomed.edu
}

Citation: Casali, B.T.; Reed-Geaghan, E.G. Microglial Function and Regulation during Development, Homeostasis and Alzheimer's Disease. Cells 2021, 10, 957. https:// doi.org/10.3390/cells10040957

Academic Editor: Alessandro Tozzi

Received: 30 March 2021

Accepted: 19 April 2021

Published: 20 April 2021

Publisher's Note: MDPI stays neutral with regard to jurisdictional claims in published maps and institutional affiliations.

Copyright: (C) 2021 by the authors. Licensee MDPI, Basel, Switzerland. This article is an open access article distributed under the terms and conditions of the Creative Commons Attribution (CC BY) license (https:// creativecommons.org/licenses/by/ $4.0 /)$.

\begin{abstract}
Microglia are the resident immune cells of the brain, deriving from yolk sac progenitors that populate the brain parenchyma during development. During development and homeostasis, microglia play critical roles in synaptogenesis and synaptic plasticity, in addition to their primary role as immune sentinels. In aging and neurodegenerative diseases generally, and Alzheimer's disease (AD) specifically, microglial function is altered in ways that significantly diverge from their homeostatic state, inducing a more detrimental inflammatory environment. In this review, we discuss the receptors, signaling, regulation and gene expression patterns of microglia that mediate their phenotype and function contributing to the inflammatory milieu of the AD brain, as well as strategies that target microglia to ameliorate the onset, progression and symptoms of AD.
\end{abstract}

Keywords: microglia; inflammation; Alzheimer's disease; neurodegenerative diseases; TREM2; neuroinflammation

\section{Introduction}

Microglia are the resident phagocytes of the central nervous system (CNS). In addition to their immunological role in maintaining CNS homeostasis, microglia play vital roles during development and during neurodegenerative diseases. Previously believed to arise from peripheral sources, microglia are now recognized as ontologically distinct macrophage-like cells. Moreover, the discovery of the unique pedigree of microglia has enabled researchers to elucidate and refine the specialized roles microglia play throughout the CNS, not only in development but also in disease. In this review, we will detail the roles microglia play during development, homeostasis and neurodegeneration, along with analysis of the specialized receptors and gene expression signatures which confer specialized microglial functions. Finally, focusing specifically on mouse models of AD, we will summarize the roles of microglia and the potential therapeutics or techniques which target them during this devastating disease.

\section{Ontogeny and Development of Microglia}

Tissue macrophage hematopoiesis arises from common myeloid precursors and occurs in two distinct waves during embryogenesis in rodents: primitive and definitive. At embryonic day 8.5 (E8.5), primitive hematopoiesis in the fetal yolk sac provides erythromyeloid precursors (EMPs) that seed the developing CNS [1]. During the second wave of definitive hematopoiesis occurring by E10.5, the fetal liver provides the bulk of tissue macrophage precursors [1]. Microglia arise exclusively from EMPs that were trafficked from the yolk sac during primitive hematopoiesis and populated the brain [1]. Zebrafish, in contrast, have multiple microglial sources. Specifically, microglia in zebrafish arise from a region analogous to the yolk sac during embryogenesis, and from the ventral wall of the dorsal aorta in adults [2].

While microglia, other tissue macrophages and peripheral monocytes all arise from EMPs [3,4], subtle differences discriminate microglial development from that of peripheral 
monocytes and other hematopoietic cells. Microglial development is dependent on the transcription factors PU.1 and IRF8 [5,6], as well as SALL1 [7], which initiate gene expression in a stepwise fashion during development [8]. This is in contrast to peripheral monocytes and macrophages which rely upon Myb1 for development [5]. Other receptors or signaling molecules also dictate microglial development and can partially impact survival, such as the cytokines interleukin 34 (IL-34), and colony-stimulating factor-1 (CSF-1) and its receptor CSF-1R [1,7,9] —explained further below. Microglial development and function are also influenced significantly by the microbiome [10]. Microbiome depletion or manipulation through germ-free conditions or antibiotic treatment results in sexually dimorphic effects on pre- and postnatal microglial transcriptional identity and function [11].

Peripheral monocytes contribute little to the microglial population in homeostasis. Adult microglia are defined by a transforming-growth factor- $\beta$ (TGF- $\beta$ )-dependent transcriptional signature, discriminating them from peripheral monocytes that invade the brain in certain experimental paradigms [12-14]. Microglia are relatively long-lived cells that rarely proliferate, except during certain CNS insults such as during neurodegeneration, where they self-renew and undergo clonal expansion $[13,15,16]$. Using transgenic mice carrying multicolor reporters, microglia underwent cell division, serving as a clone to replenish the microglial pool during homeostasis and disease, rather than a common microglial stem or progenitor cell serving as the source of new microglia [16].

\section{Microglial Functions during Development and Homeostasis}

The significant role of microglia in synaptogenesis and synaptic plasticity during development is well documented $[17,18]$. The innate immune system employs complement, a system of proteins and molecules that targets pathogens and other material for immune cell-mediated destruction. In the CNS, microglia produce the bulk of complementrelated proteins [17], although astrocytes have also been shown to express complement components [19]. During development, microglia prune synapses through recognition of the complement components $C 1 q$ or $C 3$, that tag unwanted synapses $[17,20]$. C1q is converted to $\mathrm{C} 3$, and the receptor for the $\mathrm{C} 3$ complement protein (C3R; which consists of the myeloid-specific receptor CD11b) is solely expressed by microglia. Mice deficient in C1q, C3 or C3R all demonstrate reduced microglia-dependent engulfment of synapses and show defects in synapse elimination or pruning during development $[18,20,21]$.

Other proteins on microglia restrain precocious synaptic pruning during development or postnatally. These receptors recognize "don't-eat-me" ligands expressed on neurons [22], such as CD47, which binds microglial receptor signal-regulatory protein $\alpha$ $(\operatorname{SIRP} \alpha)$. The CD47-SIRP $\alpha$ signaling axis ultimately blocks the execution of microglial phagocytosis [22,23]. The expression of CD47 and SIRP $\alpha$ is correlated with regions of active pruning during development [23]. Along these lines, mice lacking either receptor show a decreased synaptic number, and CD47 appears to be localized in active synapse regions associated with activity-dependent microglial engulfment of synapses [23].

Microglia also play pivotal roles in maintaining and contributing to the homeostasis of the neurovascular unit of the brain [24]. During development, there is a population of microglia which migrate near and along blood vessels to developing brain regions $[25,26]$. Microglia closely contact blood vessels in the murine adult brain [27], participate in the formation of new blood vessels in the retina and certain brain regions [28] and maintain contact with the vasculature not covered by astrocytic endfeet into murine adulthood [26].

During CNS development, microglia secrete or produce trophic factors which promote survival or correct the developmental trajectories of many cell types [29]. Insulin-growth factor-1 (IGF-1) promotes survival of certain types of neural progenitor cells as well as oligodendrocyte precursors during embryonic development [30,31], and specific populations of microglia in the white matter express IGF-1 and other genes implicated in lipid regulation associated with the clearance of oligodendrocytes during development of the brain [32-34]. Additionally, microglia-specific IGF-1 promotes myelination in oligodendrocytes, where adult mice with microglia devoid of IGF-1 eventually show defects in myelination [33]. 
Microglia ablation postnatally and into adulthood decreases the oligodendrocytes and oligodendrocyte progenitor cell pool in the murine brain, leading to reduced postnatal myelinogenesis [35]. These findings are suggestive of the importance of microglia and the factors they produce in supporting other glial cell populations of the brain during development and homeostasis.

Other factors directly produced by microglia, including TGF- $\beta$ and brain-derived neurotrophic factor (BDNF), promote and regulate development of the CNS. TGF- $\beta$ signaling in microglia promotes both microglial and nervous system development and behaviors in mice $[12,36]$. TGF- $\beta$ signaling also upregulates $C 1 q$ expression during development in the brain, and TGF- $\beta$-deficient animals phenocopy complement mutants and possess reduced synaptic engulfment of inputs in the retina [37]. BDNF produced specifically by microglia was found to be critical in promoting the formation of behaviors associated with learning and memory by modulating proteins involved in synaptic plasticity [38]. The absence of microglia during development results in postnatal learning task deficits and synapse formation defects [38,39]. Glutamatergic excitatory synapse function and proteins are diminished if microglia are ablated postnatally [38]. Microglia also regulate other glia cell populations and their functions during development of the CNS. Both oligodendrocyte development and their functional role in remyelination during disease are regulated to some extent by microglia [35,40,41]. The engulfment of synapses during development requires both microglia-specific receptor expression [42,43] and astrocyte-derived IL-33 for neural circuit formation [44].

In addition to microglial-mediated inputs during CNS development, microglia also monitor and modulate neuronal activity in adult rodents. Due in part to microglia-specific receptors, such as the purinergic receptor P2RY12 (see further below), microglia sense levels of metabolites released into the microenvironment by glia and neurons, directly suppressing neuronal activity and firing during homeostasis [17,39]. Mice with manipulations that preclude sensing of metabolites released from neurons possess hyperactive neuronal activity leading to a greater numbers of seizures than their wildtype counterparts [39]. This neuronal feedback through microglial activity not only controls susceptibility to seizures, but also modulates behavior, potentially creating a pivotal regulatory node during neurodegenerative contexts. Microglia also modulate memories through the complement-dependent elimination of synapses, as evidenced by studies demonstrating preserved memory recall in animals with depleted microglia or administered complement inhibitors [45]. Collectively, these findings implicate microglia in the development and regulation of neuronal homeostasis in the CNS.

\section{Microglia as Immune Sentinels}

Despite accounting for only approximately $5 \%$ of the cells in the CNS, microglia are the primary immune cell of the CNS. They are responsible for pathogen clearance, neuronal and glial maintenance and immune surveillance. In this section, we will discuss the receptors and immune-specific functions of microglia in the CNS (see Table 1 for an overview of microglia-specific receptors and signaling pathways).

Table 1. Overview of selected microglial receptors and signaling molecules during development, homeostasis and neurodegenerative diseases.

\begin{tabular}{|c|c|c|}
\hline Receptor/Ligand(s) & $\begin{array}{l}\text { Functions during Development } \\
\text { and Homeostasis }\end{array}$ & $\begin{array}{c}\text { Functions during } \\
\text { Neurodegenerative Diseases }\end{array}$ \\
\hline CX3CR1/CX3CL1 & $\begin{array}{l}\text { - } \quad \text { Synapse engulfment [18,46], and mi- } \\
\text { croglial migration. } \\
\text { - } \quad \text { Blocks neuronal excitotoxicity [47]. } \\
\text { - KO show altered behavior [48], } \downarrow \\
\text { Layer V neurons [49]. }\end{array}$ & $\begin{array}{l}\text { - } \mathrm{KO} \text { animals show enhanced } \\
\text { microglial-mediated plaque barriers, } \\
\text { and } \downarrow \text { neuritic dystrophy [50]. } \\
\text { C } x 3 \text { cr } 1 \text { downregulated in } \\
\text { DAM/MGnD phenotypes [51,52] }\end{array}$ \\
\hline
\end{tabular}


Table 1. Cont.

\begin{tabular}{|c|c|c|}
\hline Receptor/Ligand(s) & $\begin{array}{l}\text { Functions during Development } \\
\text { and Homeostasis }\end{array}$ & $\begin{array}{l}\text { Functions during } \\
\text { Neurodegenerative Diseases }\end{array}$ \\
\hline $\begin{array}{c}\text { P2RY12/Adenosine and uridine nucleotides } \\
\text { (e.g., ATP })\end{array}$ & $\begin{array}{l}\text { Metabolite sensing, protrusion exten- } \\
\text { sion [17,53] and inhibits neuronal ex- } \\
\text { citotoxicity with CD39 (Entpd1) [39]. } \\
\text { Maintains microglial regulatory junc- } \\
\text { tions between neurons [54]. } \\
\text { Controls CA1 neuron excitability } \\
\text { and fear memory [55]. }\end{array}$ & $\begin{array}{l}\text { - } \quad \text { P2ry12 and Entpd1 downregulated } \\
\text { in DAM/MGnD phenotypes [51,52]. } \\
\text { - Entpd1 KO show enhanced } \\
\text { seizures [39]. }\end{array}$ \\
\hline $\begin{array}{c}\text { TREM2/ } \\
A p o E[56], A \beta[57], \text { lipids }[56,58]\end{array}$ & $\begin{array}{l}\text { Enhances synapse elimination dur- } \\
\text { ing development [43]. } \\
\text { - Aids in astrocytic engulfment of } \\
\text { synapses during development [42]. } \\
\text { - KOs lack migratory and activation } \\
\text { profiles [59]. }\end{array}$ & $\begin{array}{ll}\text { - } & \text { Enhances microglial activation [60]. } \\
\text { - } & \downarrow \text { in microglial-plaque barrier and } \uparrow \\
\text { - } & \text { neuritic dystrophy in KOs }[61,62] . \\
& \end{array}$ \\
\hline $\begin{array}{c}\text { CSF1R/ } \\
\text { CSF-1,IL-34 [63] }\end{array}$ & $\begin{array}{l}\text { - Regulates neuronal differentiation } \\
\text { and survival in neuronal progeni- } \\
\text { tors [64]. } \\
\text { KOs of CSF1R [65] or ligands }[9,66] \\
\text { show } \downarrow \text { microglia and other myeloid } \\
\text { cell populations. }\end{array}$ & $\begin{array}{l}\text { - During experimentally-induced in- } \\
\text { jury, CSF1R expression on neurons } \\
\text { mediates their survival [67]. } \\
\text { CSF1R mutations promote spe- } \\
\text { cific type of neurodegenerative } \\
\text { disease [64]. } \\
\text { - Signaling modifies disease in } \\
\text { AD }[28,68] .\end{array}$ \\
\hline TGF- $\beta 1 /$ TGF $\beta-R 1$ & $\begin{array}{ll}\text { - } & \text { Regulates C1q expression during de- } \\
\text { - } & \text { Kelopment [37]. } \\
& \text { KO animals lack microglia [12] and } \\
\text { - } & \text { KOsnaptic plasticity [69]. } \\
\text { KOs show } \downarrow \text { motor behaviors [12]. }\end{array}$ & $\begin{array}{l}\text { - } \mathrm{CNS} \text { KO animals lack homeostatic } \\
\text { signature [12]. } \\
\text { In DAM/MGnD phenotypes, home- } \\
\text { ostatic signature is lost [52]. }\end{array}$ \\
\hline $\begin{array}{c}\text { C1q and C3/ } \\
\text { C3R (binds C3 after conversion from C1q) }\end{array}$ & $\begin{array}{l}\text { - } \quad \text { C1q and C3 tag synapses for destruc- } \\
\text { tion during development }[17,20] \text {. } \\
\text { - } \quad \text { synapses in KOs [17]. }\end{array}$ & $\begin{array}{l}\text { - } \quad \mathrm{C} 1 \mathrm{q} \text { and } \mathrm{C} 3 \text { in } \mathrm{AD} \text {, which leads } \\
\text { to synapse loss and neurodegenera- } \\
\text { tion }[17,70] . \\
\text { Microglia-specific } \mathrm{C} 1 \mathrm{q} \text { drives neuro- } \\
\text { toxic astrocytes [71]. }\end{array}$ \\
\hline CD200R/CD200 & $\begin{array}{l}\text { - CD200 expression on neurons and } \\
\text { endothelial cells inhibits microglial } \\
\text { activation in retina and brain [72,73]. } \\
\text { CD200 KO mice show enhanced } \\
\text { macrophage and microglia activa- } \\
\text { tion profiles [74]. }\end{array}$ & $\begin{array}{l}\text { - CD200 upregulation during injury } \\
\text { on neurons may protect against } \\
\text { microglial-mediated neuronal dam- } \\
\text { age }[75,76] \text {. } \\
\text { In AD human brains, } \\
\text { CD200/CD200R expression is } \\
\text { downregulated [77], and IL-4 upreg- } \\
\text { ulates CD200R in microglia during } \\
\text { neuroinflammation [78]. } \\
\text { Overexpression of CD200 in the } \\
\text { brain enhances neurogenesis and } \\
\text { promotes A } \beta \text { clearance in an AD } \\
\text { mouse model [79]. }\end{array}$ \\
\hline
\end{tabular}


Table 1. Cont.

\begin{tabular}{|c|c|c|}
\hline Receptor/Ligand(s) & $\begin{array}{c}\text { Functions during Development } \\
\text { and Homeostasis }\end{array}$ & $\begin{array}{c}\text { Functions during } \\
\text { Neurodegenerative Diseases }\end{array}$ \\
\hline $\begin{array}{c}\text { TLRs/ } \\
\text { various [80] }\end{array}$ & $\begin{array}{l}\text { Act as pattern-recognition receptors } \\
\text { to detect pathogen-associated molec- } \\
\text { ular patterns and stimuli associated } \\
\text { with innate immune responses dur- } \\
\text { ing homeostasis in the CNS }[80,81] \text {. }\end{array}$ & $\begin{array}{l}\text { - TLR4 forms a complex with A } \beta \text { - } \\
\text { binding co-receptor CD14, activating } \\
\text { microglia [82,83]. } \\
\text { Microglia lacking TLR4 show di- } \\
\text { minished phagocytosis of } \mathrm{fA} \beta \text { and } \\
\text { release of inflammatory media- } \\
\text { tors [84]. } \\
\text { Mutations in TLR4 enhance A } \beta \text { bur- } \\
\text { den and reduce microglial activation } \\
\text { in an AD mouse model [85]. }\end{array}$ \\
\hline
\end{tabular}

Abbreviations: $\mathrm{KO}$ (knockout); $\uparrow, \downarrow$ (increased, decreased, respectively).

\subsection{Microglial Receptors Linked to Immune Regulation and Neuronal Control}

Microglia express the chemokine receptor CX3CR1, whose ligand CX3CL1 (otherwise known as fractalkine) is expressed by neurons. The CX3CL1-CX3CR1 axis has been proposed to act as a regulatory node to prevent neurotoxicity through the inhibition of microglial activation [86,87]. Microglial activation is associated with a change in structure associated with the release of proinflammatory cytokines-the latter of which perpetuate neurotoxicity, synapse loss or dysregulated neuronal homeostasis [88]. Postnatal mice lacking CX3CR1 show defective microglial recruitment and reduced synaptic engulfment [46], along with diminished survival of Layer V neurons [49]. In adult mice, loss of CX3CR1 reduces synaptic plasticity in the hippocampus and promotes behavioral impairments [48].

Gene expression profiling in rodents revealed that microglia express high levels of the purinergic receptor P2RY12 relative to peripheral immune cells $[12,89]$. P2RY12 recognizes modified adenosine nucleotides, such as ATP, and enables microglial processes to rapidly respond to changes in the microenvironment, such as during injury or during neuronal homeostasis or feedback [53]. Significantly, the P2ry12 promoter selectively and robustly targets microglia over other tissue macrophages in lineage-tracing conditional mouse models [90]. The microglia-specific expression of Entpd1, the gene encoding the surface enzyme CD39, converts ATP to adenosine to initiate neuronal purinergic signaling, leading to the microglia-dependent suppression of neuronal activity [39]. Interestingly, neurodegenerative diseases are associated with diminished microglial expression of $P 2 r y 12$ and Entpd1, and mice lacking these genes show enhanced seizures and altered behavior, pointing towards the collective importance of microglia-specific regulation of neuronal activity $[39,52]$. P2RY12 is also required for specialized ultrastructural regions between microglia and neurons where microglia monitor neuronal activity directly [54]. Mutant P2RY12 animals also show reduced excitotoxicity in the CA1 and altered fear memory [55].

The triggering receptor expressed on myeloid cells-2 (TREM2) protein has increasingly been appreciated as a central player in the regulation of microglial function during development, homeostasis and disease. TREM2 mediates immune-related processes, such as migration, proliferation and survival in myeloid cells, primarily through its association with adaptor and intracellular signaling proteins [91,92]. Ligands for TREM2 appear to be related to modified lipids, lipoproteins and $\beta$-amyloid $(A \beta)$ oligomers [92]. Solely expressed on microglia in the CNS [93], TREM2 signaling mediates both the elimination of synapses by microglia and synapse engulfment via astrocytes during development and homeostasis [42,43].

CSF1R is also important for both macrophages and microglia. Microglia are reliant upon CSF1R for survival, and microglia can be efficiently depleted in adult mice with administration of certain CSF1R antagonists [94]. Mice with depleted microglia show otherwise normal cognition and behaviors [94], but these observations change in a neurodegenerative context. Other tissue macrophages also rely to some extent on CSF1R 
signaling, and mice devoid of CSF1R lack microglia and other tissue macrophages [1]. The absence of IL-34, another ligand for CSF1R, reduces microglial density $[9,66,95]$. In peripheral macrophages, CSF1R signaling promotes proliferation, survival and migration [63]. TREM2 and CSF1R signaling may coordinate to facilitate microglial survival in certain contexts [58], but it is currently unclear when this may occur.

Microglia also express other pan-macrophage receptors or markers such as CD45, IBA1, $\mathrm{CD} 11 \mathrm{~b}$ and F4/80 [96]. This fact has made microglia historically difficult to distinguish from peripheral macrophages based on surface-receptor expression alone. However, gene transcription analyses and single-cell sequencing have enabled the discovery of a microgliaspecific transcriptional signature (see further below).

\subsection{Phagocytosis, Inflammation and Microglia Polarization}

As is the case with other immune cells such as macrophages, microglia are equipped to rapidly respond to subtle changes in the microenvironment. This is due primarily to the surveillant nature of microglia, which extend highly complex and branched processes expressing sensitive surface receptors that detect extracellular signals on neurons, glia or the brain parenchyma. Upon detection of an activating stimulus, microglia execute various processes closely associated with their role as immune sentinels, such as phagocytosis and the secretion of cytokines or inflammatory mediators $[17,96]$.

Microglia are proficient phagocytes and perform phagocytosis in order to clear pathogens, apoptotic cells, aggregated proteins and lipid-associated debris $[17,96,97]$. Acting as an "eat-me" signal, exposed phosphatidylserine on the cell membrane of apoptotic cells activates surface receptors on microglia to initiate phagocytosis through rapid cytoskeletal remodeling [22]. Some prominent microglial phagocytic receptors include the MER receptor and AXL tyrosine kinases (MerTK and AXL, respectively), which activate phagocytosis only after binding to their activated cognate receptor on dying cells [98]; TREM2, which has been shown peripherally and centrally to modulate processes associated with inflammation and phagocytosis and synapse elimination [42,43,60]; and CR3, which binds to $\mathrm{C} 3$ or C1q, the latter of which decorates surfaces and act as an opsonin [17]. In contrast, microglial phagocytosis of apoptotic cells or debris can be blocked through microglial surface receptor SIRP $\alpha$ which binds to CD47 expressed on neurons, other cells or myelin [23].

Microglia also phagocytose other types of material associated with neurodegenerative diseases and myelin-associated lipids. Phagocytosis triggers the release of proinflammatory cytokines and reactive oxygen species, activating microglia $[99,100]$. The microglia-specific surface receptor TREM2 also binds material associated with neurodegenerative diseases, leading to downstream phagocytosis [57]. TREM2, MERTK and AXL have all been implicated in myelin debris clearance during certain neurodegenerative diseases [101]. Microglia also appear to be more proficient phagocytes of myelin versus peripheral monocytes [101]. In several mouse models of neurodegenerative diseases, microglial phagocytotic capacity declines with passage of the disease-most likely due to the inflammatory milieu.

Microglia become activated upon stimulation with particular agents. These stimuli induce microglia to take on a specific activation profile associated with the release of cytokines that influence the cellular milieu. Traditionally, these microglial activation profiles were referred to as "M1" and "M2", comparable to peripheral macrophages. This nomenclature categorized "M1" microglia as those that secrete pro-inflammatory cytokines or mediators, such as IL-1 $\beta$, TNF- $\alpha$, IL-6 and reactive oxygen species [102]. In contrast, "M2" microglia secrete cytokines or mediators associated with immune resolution, phagocytosis and wound healing, such as IL-4, IL-13, IL-10 and Arg1 [103]. It is now clear that cytokines classified as anti- or pro-inflammatory do not produce their expected phenotypes in transgenic mouse models of disease. Thus, the general consensus in the field has evolved to discourage the application of the terms "M1 or M2", since microglia and macrophages can exist as a heterogeneous population of cells with differing states of activation $[102,104,105]$. It is now known that microglia show a specific gene expression signature differing from 
these M1- or M2-activation profiles induced in peripheral macrophages [52]. We will therefore not refer to microglia as M1/M2, but reference the specific cytokines involved. Thus, microglia act as specialized and unique immune sentinels of the CNS during both homeostasis and during disease.

\section{Microglia in Aging and Neurodegenerative Diseases}

Microglia regulate pathologies during neurodegenerative diseases such as AD, Parkinson's disease (PD) and multiple sclerosis (MS) [106,107]. PD is characterized by motor dysfunction and eventual dementia due to the neurodegeneration of dopaminergic neurons in the substantia nigra as a result of the accumulation of misfolded neuronal $\alpha$-synuclein [108]. MS is a chronic, inflammatory neurological disorder characterized by lesions of demyelinated nerves in the brain and spinal cord-eventually compromising autonomic, sensory, motor and cognitive functions [107]. MS is thought to arise due to defects in myelination or the immune-mediated destruction of myelinated fibers. Where applicable, we will discuss microglia involvement during these diseases, but we will focus most on microglia during AD.

\subsection{Normal Aging}

There is some evidence that aging influences microglial function. Although microglia adopt a specific transcriptional signature during neurodegenerative diseases, aging may impose distinct transcriptomic changes. In general, aging may foster a more pro-inflammatory brain microenvironment, rendering microglia more sensitive to stimuli $[100,109]$. Aging can also promote a chronic state of inflammation in macrophages in the periphery, otherwise known as "inflammaging", which may also extend to microglia [109-111]. In both humans and rodents, a subset of microglia progressively become laden with lipids during aging [97]. These "lipid-droplet accumulating" microglia show upregulation of pro-inflammatory cytokines, are defective phagocytes and possess a gene signature similar to that driven by innate immune stimuli such as bacterial endotoxins [97]. Some genes upregulated by these microglia are connected to neurodegenerative disorders [97]. In aging humans, microglia downregulate pathways and proteins associated with homeostasis, such as TGF- $\beta$ [112]. While sharing some overlap, aging microglia show pathways that differ from microglia during neurodegenerative disorders [113]. Generally, aging alters microglia-specific genes associated with activation and phagocytosis throughout most regions of the brain, including areas commonly exhibiting AD pathology [114,115]. Nonetheless, these findings suggest aging imposes microglial phenotypes associated with an overall divergence from homeostatic processes.

\subsection{Microglia during $A D$}

$\mathrm{AD}$ is characterized by cognitive decline due to the accumulation of two pathological hallmarks: extracellular dense-core $\beta$-amyloid $(\mathrm{A} \beta)$-containing plaques and intracellular neurofibrillary tangles composed of the hyperphosphorylated microtubule-binding protein tau [116]. These pathological hallmarks create an inflammatory microenvironment characterized by reactive gliosis that propels neurotoxicity and neuron loss [88,116]. According to the Alzheimer's Association, AD affected more than 5 million Americans in 2020 [117], and limited therapeutics exist to promote disease resolution or diminish symptom severity. Age is the greatest risk factor for $\mathrm{AD}$, though enhanced risk is associated with the expression of certain apolipoprotein (ApoE) isoforms, encoded by the APOE gene [118], the immune system, cholesterol homeostasis and microglia. Studies have pointed to the expression of polymorphisms associated with risk genes such as CLU, BIN1, ABCA7, TREM2 and CD33 as risk factors for AD [119,120], all tied to microglia and the immune response. Aside from microglia-specific TREM2 and CD33, which collaborate in mouse models of AD to regulate pathology [121], other genes found in genome-wide association studies have been shown to modify pathology in various AD mouse models [121-125]. In human cases of AD, the expression of TREM2 variants was shown to confer enhanced risk for AD [126,127]. The 
majority of risk genes are implicated in immune and cholesterol regulation, both of which are often perturbed in neurodegenerative diseases [128,129]. Microglia execute pivotal functions and roles which can contribute to disease regulation and progression during AD, discussed below.

\subsection{A Clearance}

One hallmark of AD pathology is the accumulation of extracellular $A \beta$, which is produced following a series of cleavage events of a precursor protein in neurons by membrane-bound enzymes. Soluble $A \beta$ monomers can accumulate in the extracellular space, eventually fibrillizing into insoluble aggregates and dense-core plaques. Both soluble and insoluble forms of $A \beta$ are cleared through different mechanisms $[130,131]$. Microglia efficiently promote clearance of both soluble and insoluble forms of $A \beta$.

Soluble forms of $\mathrm{A} \beta(\mathrm{sA} \beta)$ are chiefly cleared through macropinocytosis in microglia [130]. In this process, $\mathrm{SA} \beta$ is taken up in microglial cells and targeted for intracellular proteolytic degradation [131]. Degradation of $\mathrm{sA} \beta$ is enhanced by and dependent upon the lipidation status of ApoE high-density lipoproteins (ApoE-HDLs) [132]. Therapeutics enhancing genes associated with ApoE production and its lipidating receptors produce salutary outcomes in various animal models of neurodegenerative diseases, including AD [131,133]. Microglia have been shown to secrete ApoE-HDLs which differ in their propensity to be lipidated relative to astrocyte-derived ApoE-HDLs [134]. Whether these glial-specific ApoE-HDLs differentially impact neurodegenerative disease is unclear.

The clearance of insoluble or fibrillar $A \beta$ (fA $\beta$ ) and plaques is mediated solely by microglia via a complex of surface receptors that culminate in the delivery of $f A \beta$ to the lysosome for degradation [84,135-138]. Envelopment of $f A \beta$ or plaques induces the release of pro-inflammatory cytokines which may promote neurotoxicity [88]. The presence of antiinflammatory cytokines or mediators, such as IL- 4 , augments fA $\beta$ phagocytosis, whereas a microenvironment with pro-inflammatory cytokines, such as IL-6, blocks fA $\beta$ phagocytosis in microglia $[99,139]$. Drugs such as nuclear receptor agonists bexarotene, pioglitazone and GW3965 promote the upregulation of scavenger receptors or genes associated with phagocytosis, ameliorating AD pathology in various mouse models [131,133,140,141].

\subsection{Microglial-Mediated Plaque Barrier Function and Neuroprotection}

While microglia become less efficient at phagocytic clearance of $A \beta$ with time, microglia nevertheless maintain contact with plaque borders throughout disease [142]. In humans and in mouse models of $\mathrm{AD}$, microglia form a barrier around dense-core plaques. They remodel plaque perimeters to limit newly formed soluble $A \beta$ from binding to highaffinity $A \beta$ 'hotspots' - regions containing less $A \beta$ and not covered by microglia processes [143]. Another purpose of the microglia barrier is to impede plaque edges from damaging nearby healthy neurites via direct-contact of the plaque by microglial processes [143]. Overall, the degree of plaque compaction is directly correlated with the degree of plaque-associated neuritic dystrophy [143]. Therefore, microglial barriers appear to be the most efficient at restraining neuritic dystrophy spread around smaller plaques [50]. Inhibition of either CX3CR1, the microglial receptor responsible for chemotaxis and synaptic plasticity, or plaque engagement via $\mathrm{A} \beta$-directed antibodies by microglia, ameliorates plaque compaction and microglial coverage, and reduces neuritic dystrophy [50]. On the other hand, the microglia-specific receptor TREM2, which controls phagocytic processes, is required to form efficient microglial-mediated barriers around plaques in various mouse models of AD [50,61]. Microglial depletion precludes barrier formation but is reversible $[144,145]$. Thus, microglial-mediated plaque barriers promote neuroprotection in many mouse models of AD.

\subsection{Inflammation and Polarization}

During disease, $\mathrm{A} \beta$ is associated with microglial activation, the release of pro-inflammatory cytokines and subsequent neurotoxicity $[88,116]$. Depending on disease stage, microglial 
inflammation and polarization may influence disease progression in AD [146]. Broadly, inflammation-associated signaling in microglia can be regulated at the level of surfacereceptor expression, or through transcriptional blockade of cytokines and inflammatory mediators. CX3CR1 appears to block microglial activation to mediate neurotoxicity [87], and certain surface receptors, such as TREM2, may be shed from the surface to create a soluble counterpart in order to modify pathology [147]. The mechanisms by which soluble TREM2 regulates inflammation are unclear. Nuclear receptors (explained further below) both inhibit transcription of pro-inflammatory cytokines and promote the upregulation of genes associated with the suppression of inflammation and $A \beta$ clearance [131].

Microglia-specific receptors impact $\mathrm{AD}$ pathology and progression in various mouse models. Mice lacking CX3CR1 show reduced plaque burden and neurotoxicity in amyloiddriven mouse models, whereas transgenic mice overexpressing tau show worsened behavior and microtubule-associated pathology [148-151]. Additionally, CX3CR1 loss promotes neuron loss in mouse models of AD [148]. Microglia progressively lose a gene signature associated with homeostasis upon induction of neurodegenerative diseases, which is marked by downregulation of $C \times 3 \operatorname{cr} 1$ [51].

TREM2 manipulation, either through genetic deletion or antibody-dependent activation, may have different effects on pathology in various amyloid- and tau-expressing AD mouse models [152-156]. Soluble forms of TREM2 also appear to modulate AD pathology through direct action on microglial phenotypes $[157,158]$. Nonetheless, TREM2 or TREM2 variants appear to modulate microglial activation. Downstream of TREM2 signaling, the microglia-specific receptor CD33 controls uptake of $A \beta$ in AD mouse models [159], contributing to disease progression [121].

The glycoprotein CD200 is expressed by neurons, glial cells, leukocytes and endothelial cells [73]. Its receptor, CD200R, is expressed chiefly by microglia and myeloid cells. The CD200-CD200R signaling axis delivers inhibitory signals to block microglia activation in the brain and retina [72,73]. Along these lines, CD200 knockout mice show macrophages and microglia with enhanced proinflammatory cytokines and activated phenotypes [74], whereas anti-inflammatory cytokine IL-4 promotes the upregulation of CD200R in microglia [78]. During injury, CD200 is upregulated on neurons, where it may act to inhibit microglia [75,76]. In neurodegenerative diseases, such as AD, CD200 is downregulated in human brains [77], and forced overexpression in the brain of CD200 promotes neurogenesis and ameliorates pathology in a mouse model of $\mathrm{AD}$ [79].

Secreted cytokines and proteins derived from microglia can exacerbate disease. Using microglia depletion and knockout mice, studies demonstrated that the microglia-dependent release of cytokines TNF $\alpha$, IL- 6 and the complement protein C1q induce the conversion of quiescent astrocytes into neurotoxic astrocytes displaying a specific gene signature associated with neurodegeneration [71]. Microglia-specific complement proteins and receptors play key roles in exacerbating disease, especially early in disease where C1q promotes $\mathrm{A} \beta$-induced synapse elimination in the hippocampus and subsequent behavioral impairments [70]. C1q promotes oligomeric $A \beta$-associated neurotoxicity in the hippocampus, and blockade of $\mathrm{C} 3$ or $\mathrm{C} 3 \mathrm{R}$ signaling retains synapses in an AD mouse model [70]. Although these components facilitate the removal of synapses and neurons by microglia during development and homeostasis, neurodegenerative diseases are associated with the upregulation of C1qa and C3 proteins [17]. This leads to microglial-mediated synapse elimination and neurodegeneration.

Toll-like receptors (TLRs) act as pattern-recognition receptors and detect innate immune stimuli associated with pathogens or cell damage [81]. Activation of these receptors initiates the proliferation, activation and clearance of $A \beta$ in microglia [80]. One prominent example is TLR4, which forms a complex with the A $\beta$-binding co-receptor CD14 in microglia [82,83]. Microglia lacking TLR4 show hampered phagocytosis of fibrillar A $\beta$ and abrogated release of cytokines [84]. Furthermore, loss-of-function mutations in TLR4 exacerbate $\mathrm{A} \beta$ burden and impair microglial activation in mouse models of AD [85], collectively highlighting the importance of TLR activation in AD. The functions and phenotypes 
associated with other TLRs have been characterized and summarized during homeostasis and disease in the CNS; however, this topic is beyond the scope of this review and detailed elsewhere [80,160,161].

Originally characterized in peripheral macrophages, inflammasomes recognize danger signals associated with the self or toxins, such as oxidized lipoproteins, asbestos, sodium urate crystals associated with gout and fibrillar forms of A $\beta$ [162]. Activation of the inflammasome culminates in cell-mediated pyroptosis, a caspase-dependent type of cell death associated with inflammation [163]. Additionally, subunits of the inflammasome complex can be released from microglia, whereupon they promote enhanced seeding and accumulation of $\mathrm{A} \beta$ plaques in an AD mouse model due to their prionoid-like activity $[164,165]$. Interestingly, both amyloid- and tau-expressing AD mouse models demonstrate ameliorated pathologies when components of the inflammasome are deleted [166,167], pointing to the importance of immune components and mediators in microglia (see Table 1 for a summary of microglia-specific receptors and signaling involvement during AD).

\subsection{Homeostasis and Neurodegeneration Exhibit Distinct Microglial Gene Signatures}

Although microglia and peripheral macrophages execute similar functions, such as cytokine release and phagocytosis of debris and pathogens, microglia possess unique regulatory mechanisms during homeostasis and during disease. Our recent understanding of the transcriptional differences during homeostasis and disease in microglia from that of other tissue phagocytes has been due to the advances of single-cell sequencing and flow cytometric technologies. In this section, we will focus on the transcriptional signatures defining microglia during tissue homeostasis and how this unique transcriptional framework subserves microglia functions during neurodegenerative diseases.

In the non-diseased CNS, microglia exist in a homeostatic state and express a unique transcriptional signature that differs from non-CNS tissue macrophages. This homeostatic signature is defined by high expression levels of surface proteins CX3CR1, P2RY12, TMEM119 and TGF- $\beta$ receptor 1 (TGFBR1), along with various transcription factors and other genes [96,168]. During neurodegenerative diseases, microglia adopt a collective signature significantly different from the homeostatic transcriptional signature. These "disease-associated microglia" (DAM) acquire a gene signature collectively associated with a "microglial neurodegenerative (MGnD)" phenotype. Although most research has focused on rodent neurodegenerative models, DAM-like cells have been observed in human AD brains [52].

The acquisition of DAM-like cells occurs temporally, with some studies suggesting various stages of DAM based on marker expression alone [51]. The first step coincides with the downregulation of the homeostatic genes Cx3cr1, P2ry12 and Tmem119, which encode their respective surface receptors normally expressed at high levels in microglia [51,169]. Some homeostatic receptors provide known inhibitory signaling, as is the case with CX3CR1 and its cognate neuronal ligand CX3CL1, which provides protection against microglialmediated neurotoxicity [47]. The downregulation of homeostatic genes coincides with the upregulation of specific DAM or MGnD-associated genes, such Trem2, Apoe, Lpl, Cst7, Spp1 and Clec7a, among others $[96,169]$. The majority of these genes are associated with the production of proteins involved in lipid metabolism, phagocytosis, clearance of apoptotic cell bodies and the immune response $[96,129,169,170]$. Interestingly, the MGnD phenotype is consistent across various neurodegenerative mouse models. DAM-like cells or MGnD phenotypes have been characterized in the A $\beta$-producing $5 x F A D$ and APP/PS $\triangle E 9$ AD mouse models [51,171,172], the Tau-producing P301S AD mouse model [173], mouse models of amyotrophic lateral sclerosis [51,52,174] and mouse models for multiple sclerosis [52]. 
The expression of certain receptors and transcription factors controls the expression of the homeostatic microglial signature (Figure 1). A key determinant of the microgliaspecific gene signature is the expression of Tgfbr1, encoding the TGFBR1 that binds TGF$\beta 1$. This microglia-specific TGF- $\beta$-defined signature is distinct from peripheral tissue macrophages [12], but there are some instances when monocytes may adopt a TGF- $\beta$ dependent signature [175]. High expression of Tgfbr1 is observed in homeostatic microglia $[36,52]$. Mice devoid of TGF- $\beta 1$ in the CNS showed reduced numbers of microglia, lacked homeostatic-like microglia signatures and displayed enhanced mortality due to paralysis compared to wildtype littermates [12,36]. Activation of SMAD proteins downstream of TGF- $\beta$ receptors induces homeostatic-like gene repertoires in microglia [176]. The transcription factor SALL1, whose expression is restricted to microglia compared to other tissue phagocytes, maintains homeostatic microglia, and its deletion leads to impaired neurogenesis and renders microglia more inflammatory and phagocytic [7]. In the adult rodent, certain homeostatic functions are conferred by the expression of transcription factors $M a f b$ and Mef2a, both of which are induced in a stepwise fashion during development [8]. The transcription factor PU.1, which is highly expressed by myeloid cells and required for microglial development, shows enrichment in binding sites for other microglia homeostatic transcription factors, thereby facilitating microglia-specific signatures [6,177-179]. In DAM/MGnD phenotypes, these aforementioned transcription factors are suppressed [96].

The control of microglial homeostasis involves several regulatory nodes in the form of surface proteins and transcription factors. Most of this regulation is due in part to microglial surveillance of the environment. In the neurodegenerative context, some have proposed that microglia sense and respond to neurodegeneration-associated molecular patterns, otherwise known as NAMPs [169]. Molecularly, NAMPs function similarly to pathogen-associated molecular patterns (PAMPs) present on bacteria and viruses. Examples of NAMPs include extracellular protein aggregates composed of A $\beta$, apoptotic neurons, myelin debris and extracellular lipid degradation products [169]. Certain "classical activation" ligands (e.g., bacterial endotoxins) that polarize peripheral macrophages towards a classic inflammatory gene expression profile do not induce the DAM/MGnDphenotypic signature in microglia, although minor gene expression overlap does occur [52]. These findings further support the notion that the underlying mechanisms for DAM gene signature acquisition are specific to microglia and could be due to unique microglial ontogeny. On the other hand, DAM cells could be a result of microglial reactivity to misfolded protein aggregates, the latter of which are hallmarks of many neurodegenerative diseases.

DAM cells are often proximal to various NAMPs, whereas microglia further from NAMPs maintain a homeostatic profile. For example, microglia around apoptotic neurons or A $\beta$-associated dystrophic neurons show high expression of CLEC7A and low levels of the homeostatic protein P2RY12, whereas microglia associated with non-diseased neurons possess the inverse profile [52]. In AD mouse models, the expression of microglia surface receptor CD39 (encoded by Entpd1) becomes downregulated, suppressing microglial regulation of neuronal activity [39,52]. Microglia sensing of NAMPs initiates innate immune signaling and concomitant transcriptional activation of the MGnD/DAM phenotype, enabling microglia to block pathological effects from neurodegenerative byproducts through the phagocytosis of $A \beta$ or microglial-mediated barrier formation to promote plaque compaction and lessen plaque-associated neuritic dystrophy, for example [50,61]. Manipulation of CX3CR1 signaling has been shown to abrogate plaque burden in an AD mouse model, though the authors of the original study did not analyze DAM/MGnD phenotypic gene signatures [149]. On the other hand, DAM-like cells may also promote neurodegeneration if microglia lose the ability to maintain homeostatic functions [52]—see Figure 1. 


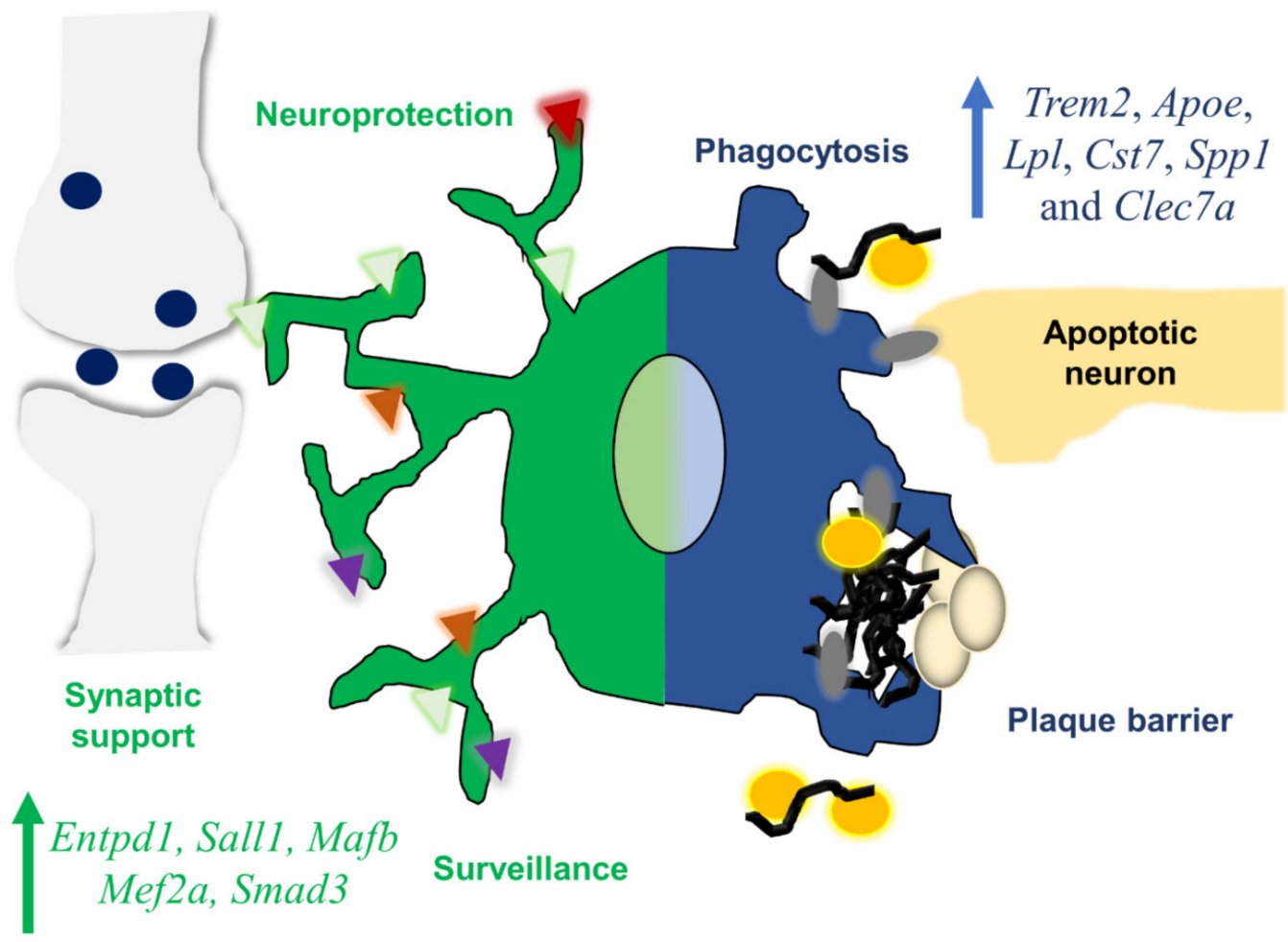

Homeostatic phenotype

DAM/MGnD phenotype

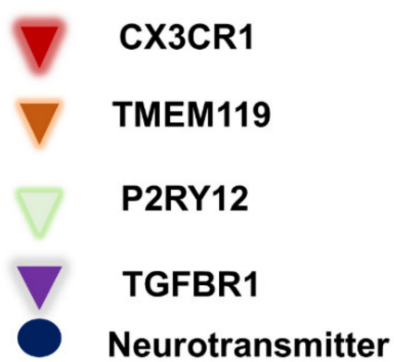

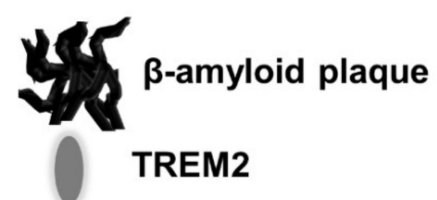

ApoE

Dystrophic neurites

Figure 1. Regulation of the homeostatic and DAM/MGnD phenotypes. The homeostatic phenotype (green) is associated with phenotypes associated with microglial-mediated neuroprotection, synaptic support and immune surveillance. Surface receptors are upregulated in the homeostatic state, such as CX3CR1, TMEM119, P2RY12, TGFBR1 and CD39, encoded by Entpd1, all of which facilitate homeostatic responses. Homeostatic microglia display key transcription factors, such as Sall1, Mef2c and Smad3. Onset of neurodegenerative-associated pathology such as A $\beta$, or apoptotic neurons, triggers downregulation of homeostatic surface receptors and upregulation of the DAM/MGnD phenotype (blue)-the latter associated with markers Trem2, Apoe, Lpl, Cst7, Spp1 and Clec7a. Phagocytosis of apoptotic neurons and phagocytosis of A $\beta$ is performed via TREM2- or ApoE-mediated recognition signals in microglia. ApoE and TREM2 coordinate expression of DAM/MGnD genes, as well as facilitate formation of the microglial-mediated plaque barrier to protect neighboring neurons from dystrophic neurite spread.

\subsection{ApoE Regulation of DAM/MGnD Phenotype}

Though many genes are altered in the DAM/MGnD phenotype, most advances in our understanding of microglial biology during disease have centered on microglia-specific proteins and ApoE, the greatest risk factor for late-onset AD after age [180]. In particular, the microglia-specific surface protein TREM2 is pivotal in regulating the DAM and MGnD phenotypes. Microglia from TREM2-deficient mice possess a dampened gene activation 
profile, and fail to migrate to apoptotic or injured neurons [59]. Forced overexpression of TREM2 ameliorates the chemotactic deficiencies [59], pointing towards the critical role TREM2 signaling plays in microglial activation. Interestingly, expression of $C c l 2$, which encodes the chemokine responsible for mediating monocyte and microglia migration through binding to chemokine receptor CCR2, is upregulated in DAM microglia [52]. TREM2-null AD mice lack a DAM signature and MGnD phenotype, and these mice possess enhanced neuroprotection in young mice versus TREM2-expressing AD littermates [51,52]. Additionally, the overexpression of TREM2 abrogates AD pathology via the upregulation of genes involved in phagocytosis, immune regulation and neuroprotection, culminating in reduced plaque burden and diminished neuritic dystrophy in the 5xFAD mouse model [181]. Others have demonstrated that DAM transformation occurs in two steps, with the final stage of DAM acquisition being dependent on TREM2 signaling [51]. Besides binding to A $\beta$ [57], TREM2 also acts to sense levels of various lipoproteins such as ApoE that are found in plaques and could promote plaque seeding $[56,58,182,183]$.

The DAM/MGnD-phenotype is characterized by the robust expression of Apoe, which encodes ApoE, and its expression is negatively correlated with that of the homeostatic marker Tgfb1 in various models of neurodegeneration [52]. Aside from the multifaceted roles ApoE plays in AD [180], its signaling in microglia is currently an active area of research. Microglia that do not express ApoE lack a complete DAM signature, and mice with Apoe-deficient microglia also show increased neuroprotection in a model of acute neuronal ablation [52]. Interestingly, MGnD phenotypes were only observed in microglia phagocytosing apoptotic neurons - microglia not phagocytosing apoptotic neurons lacked a complete MGnD phenotype or DAM acquisition [52]. AD mouse models with global Apoe deletion possess microglia with reduced activation profiles [52,184]. These mice also lack microglial plaque barriers and exhibit enhanced neuritic dystrophy due to reduced plaque compaction [184]. Along these lines, reduced plaque-associated ApoE and microglial clustering around plaques were observed in AD mice lacking TREM2 [185]. On the other hand, plaque seeding was enhanced in these animals, suggesting that ApoE activates microglia around or near plaques.

Though the underlying signaling mechanisms are still active areas of research, TREM2, in concert with ApoE, plays fundamental roles in controlling DAM and MGnD phenotypes. Nonetheless, it is currently a matter of debate and active research, whether DAM or MGnD phenotypes per se are harmful or beneficial in the context of neurodegenerative diseases [96].

\subsection{The Role of Myeloid Cells at Brain-Border Interfaces in Neurodegenerative Diseases}

The CNS experiences little infiltration from the peripheral immune system during homeostasis; however, the peripheral immune system contributes significantly to certain neurodegenerative diseases, such as in experimental autoimmune encephalomyelitis (EAE) mouse models of MS. These studies have generated considerable controversy about the relative contribution of the peripheral immune system in the CNS during other neurodegenerative diseases. Some work demonstrated that bone marrow-derived monocytes infiltrated the brain during neurodegenerative diseases such as AD [186]; however, these studies utilized either whole-body or brain-shielded irradiation, both of which damage the blood-brain barrier (BBB), promote radiation-dependent gene upregulation in brainresident microglia [187-190] and alter the brain's microenvironment to permit monocyte infiltration [191]. Similarly, other studies have employed genetic models that ablate microglia, triggering an influx of peripheral monocytes into the brain in order study the peripheral immune system during homeostasis and neurodegenerative diseases [13,14,192]. Infiltrating monocytes then differentiated to adopt a ramified, microglia-like morphology upon extravasation into the parenchyma [13,14,192], but these monocytes maintained a transcriptional signature distinct from resident microglia [13]. In contrast, studies using strategies less disruptive to the blood-brain barrier (BBB), including parabiosis or cell- 
specific lineage tracing, refute that work, instead demonstrating that the infiltration of monocytes into the brain is minimal, even during AD [193,194].

In addition to the microglia that survey the brain parenchyma, myeloid cells exist within the anatomical spaces and regions bordering the brain. The choroid plexus $(\mathrm{CP})$, meninges and dura and pia mater contain myeloid cells collectively referred to as borderassociated macrophages (BAMs). The majority of BAM subsets exhibit transcriptional signatures significantly distinct from those of circulating monocytes and parenchymal microglia; however, one known subset of BAM possesses a transcriptional signature similar to that of parenchymal microglia. Collectively, BAMs share a resting gene signature that is distinct from homeostatic microglia, with each subset expressing a unique cadre of genes. All BAMs, however, show high expression levels of Apoe, Ms4a7 and Lyz2 relative to resting microglia [171]. Ms4a7 encodes the multipass proteins of the tetraspan MS4A family expressed in macrophages and microglia. MS4A family members have been shown to modulate TREM2 levels and confer enhanced AD risk [195,196]. Epiplexus BAMs, which reside on the $\mathrm{CP}$ epithelium, possess a resting gene signature that most closely resembles the DAM/MGnD phenotype, with high expression of lipid and phagocytic-related genes Apoe, Cst7, Clec7a and Lpl [171]. Thus, CP epiplexus BAMs most resemble parenchymal microglia. Along these lines, $\mathrm{CP}$ epiplexus BAMs and parenchymal microglia can be selectively targeted with the Sall1 promoter [171,197].

In terms of myeloid-specific transcription factors, nearly all BAMs rely on PU.1 for survival and are independent of other common monocyte-related transcription factors such as Myb1 [198]. Interestingly, when the transcription factor IRF8 is silenced in microglia, this cell population adopts a signature similar to that of BAMs, lending credence to the indispensable role IRF8 plays in microglia-specific ontogeny [171]. IRF8 is required for the development of microglia [6], tissue macrophages [199] and other myeloid cells [200]. Anatomical locations more proximal to the blood, such as the $\mathrm{CP}$ and dura, show significant monocyte contribution during steady state; however, nearly all BAMs show some self-renewal capacity $[171,198]$. Like parenchymal microglia, macrophages at the brainborder interfaces are also susceptible to depletion via small-molecule inhibitors against CSF-1R $[94,171,197]$. Collectively, these findings suggest that despite unique transcriptional profiles, to some extent, microglia and BAMs rely on common macrophage-specific receptors for survival.

The lymphatics in proximity to the border-associated regions, such as the meninges, are critical gateways for other immune cells to interact with cerebral spinal fluid (CSF) in draining lymph nodes nearest the CNS to influence neurodegenerative diseases. Ablation of meningeal lymphatics ameliorates recovery in a mouse model of MS due to dampened neuroinflammation [201]. In contrast, AD mouse models lacking meningeal lymphatic drainage demonstrate enhanced parenchymal $\mathrm{A} \beta$ plaque deposition in the meninges and in the parenchyma [202]. Thus, myeloid cells at anatomical border sites may play different roles compared to parenchymal microglia depending on the type of neurodegenerative disease.

The precise roles BAMs play during aging and neurodegenerative diseases are unresolved. Nonetheless, relative BAM populations shift in aging and mouse models of AD, depending on marker classification [171,197]. In EAE mouse models of MS, T cells and peripheral monocytes represent the bulk of infiltrative immune populations, but BAMs maintain an activating signature distinct from the invading peripheral monocytes [197]. Moreover, macrophages associated with the vasculature self-renew through acute and chronic phases of the disease during EAE progression [198]. Interestingly, CP epiplexus BAMs maintain a DAM/MGnD phenotype in an AD mouse model, and these BAMs exhibit a high phagocytic capacity, probably owing to the fact that the $\mathrm{CP}$ stroma directly interfaces with the lipid and lipoprotein-containing CSF [171]. 


\section{Targeting Microglia during Development and Disease}

Since there are no targeted therapeutics to control or reverse the symptoms of AD, there is immense clinical interest in developing novel drugs to target receptors, pathways or cell groups. While much attention has been given to therapeutics that ameliorate pathology in $\mathrm{AD}$ mouse models, the recent advances in the unique microglial biology and function have a greater therapeutic potential for the treatment of AD specifically, and neurodegenerative diseases more broadly. In this section, we will discuss genetic models to target microglia during development and disease as well as specific agents which modulate microglia or microglial functions during disease. Though these models are not yet ready for clinical use and are not likely to be logical therapies themselves, they provide critical avenues by which researchers can study the functions of microglia during development and homeostasis, thereby identifying conducive therapeutic targets and strategies.

\subsection{Genetic Models to Target Microglia}

Since macrophages are phenotypically indistinguishable from microglia, it has been traditionally difficult to selectively target microglia in rodent models. The LysM-Cre models, which drive Cre-recombinase under the Lyz2 promoter, can be used to target subsets of microglia during development. However, the ubiquitous expression of $L y z 2$ by peripheral myeloid cells and low targeting efficiency of microglia, as well as expression in neurons, potentially confound its use for microglia-specific targeting [203-205]. The chemokine receptor CX3CR1 has been reported to label various tissue macrophages, dendritic cells, monocytes and microglia in knock-in and conditional models crossed to reporter lines [206]. Animals expressing a mutant Cre enzyme fused to a modified estrogen receptor (CreER) can be induced to express fluorescent reporters after tamoxifen administration [206]. With this inducible model, the above populations are targeted, but dendritic cells and circulating monocytes undergo rapid replacement by tamoxifen-naïve precursors relative to microglia, the latter of which do not show appreciable turnover. According to some studies, the fidelity for targeting microglia with the Cx3cr1-CreER model approaches or exceeds 90\% [206,207]. This model has been successfully used to label and track microglia during development and disease, but also has been utilized to delete genes flanked by loxP sites ("floxed" alleles) solely in microglia. TMEM119, a robust marker for homeostatic microglia, can be utilized to modify or label microglia in transgenic mice, but some fibroblasts and myeloid populations associated with the brain border may also be targeted $[208,209]$. The homeostatic receptor P2RY12 can also be used to efficiently target microglia [90]. Even still, Sall1-CreER targets microglia and a subset of epiplexus CP BAMs [7,171], whereas Cx3cr1CreER and P2ry12-CreER target both microglia and nearly all types of BAM cells to some extent $[90,198,210]$. It is important to note that the expression of these homeostatic markers diminishes during disease progression, and particular attention should be exercised as to the timing of gene deletion or manipulation. Thus, there are various mouse models at the disposal of researchers to target microglia during development and disease, but off-target cell effects should also be considered associated with these models.

\subsection{Microglia Depletion and Targeting Microglial Receptors during Homeostasis and Disease}

Microglia rely on CSF1R signaling in some capacity for survival, as using certain CSF1R inhibitors eliminates microglia in mouse models [28,94]. Depending on the paradigm used, microglial depletion efficiency approaches $98 \%$ [94], similar to other genetic strategies to eliminate microglia [211,212]. Nevertheless, microglial depletion may be less efficient in certain disease contexts such as $\mathrm{AD}$ [213]. It is unclear whether microglia resistant to depletion rely on other survival signals aside from CSF1R, but evidence strongly suggests other receptors, such as TREM2, may provide compensatory survival pathways [58]. A recent study suggested depletion-resistant microglia may derive from a microglia-like progenitor cell similar to the EMPs from which microglia arise [214]. Additionally, plaque-associated microglia downregulate Csf1r upon transition to DAM-like cells [52], and microglia from mice with enhanced plaque burden are resistant to CSF1R-mediated depletion [144,145]. 
In almost all cases, microglia repopulate through self-renewal following drug removal, exhibiting nearly identical gene signatures and functions relative to their non-depleted counterparts in a homeostatic environment $[94,215]$. Under certain experimental conditions, peripheral monocytes do contribute to the repopulating microglia pool, but both cell types maintain distinct transcriptional signatures $[13,14,216,217]$. Microglia depletion during adulthood in mice and rats does not negatively affect behavior or cognition [94,215]. On the other hand, the elimination of microglia embryonically or postnatally alters juvenile and adult anxiety-like behaviors in mice and rats [218,219].

In amyloid-exclusive mouse models of $\mathrm{AD}$, both disease progression and duration of CSF1R-inhibition dictate the impacts of microglia depletion on pathology (Figure 2A). Longterm microglial depletion (e.g., three or more months) prior to plaque deposition improves behavior and prevents plaque formation in the parenchyma, except in the vasculature where microglia persisted $[144,220]$. Acute depletion of microglia prior to plaque deposition is also neuroprotective, by rescuing dendritic spine and neuronal loss [213]. Microglial depletion at peak pathology in an $\mathrm{AD}$ mouse model reduces plaque burden, alters plaque morphologies and accelerates neuritic dystrophy, but these effects revert upon microglial repopulation [145]. In older AD mouse models, transient elimination of microglia does not affect $\mathrm{A} \beta$ burden, but neuroinflammation is reduced and certain behavioral tasks are improved [213]. The depletion of microglia does not impact behavior early in disease [144]. These varied outcomes illustrate the complexity of microglial function.

There is a possibility that repopulated microglia may be able to execute more efficient disease-modifying functions, but this could depend on the time course of the disease or the type of disease $[145,213,221]$. It should also be noted that CSF1R inhibition, or genetic models to deplete microglia, can alter peripheral myeloid and lymphoid cell population numbers in addition to microglia [222,223]. This finding could impact prior studies where significant input of the peripheral immune system occurred in the context of CNS disorders. Another point to consider is that microglia depletion models show enhanced cytokine storm and astrocytosis $[13,94,216]$. Some CSF1R inhibitors do not deplete microglia, but rather hinder microglial functions, such as proliferation, activation and migration-consistent with CSF1R inhibition in peripheral macrophages $[63,224]$. In some of these studies, the inhibition of microglia proliferation or activation did not alter plaque burden, but rather shifted plaque-associated microglia to an anti-inflammatory phenotype, corresponding to improved cognitive and behavioral outcomes in an AD mouse model [225]. Thus, microglia depletion in $\mathrm{AD}$ is a novel means to a therapeutic approach for $\mathrm{AD}$, but also to uncover the mechanisms which underlie microglia-dependent processes in AD.

Targeting microglia specifically appears to be an attractive option. Specific microglial receptors, such as TREM2, provide an initial signal for DAM/MGnD activation by binding to ApoE $[51,52,56]$. Along these lines, recent studies have shown that humanized antibodies targeting TREM2 promote microglia activation, reduce pathology, correct cognitive deficits and dictate microglial responses even in AD mouse models carrying TREM2 variants $[153,154,226-228]$. This is particularly important, as some TREM2 variants, such as TREM2-R47H [126], are considered loss-of-function mutations and are associated with worsened pathology in AD mouse models [62]. The overexpression of TREM2 also ameliorates pathology and reverses cognitive deficits in an AD mouse model through microglia activation [181]. Therefore, therapeutics that recalibrate microglial activation through TREM2 are particularly attractive (Figure 2B). 

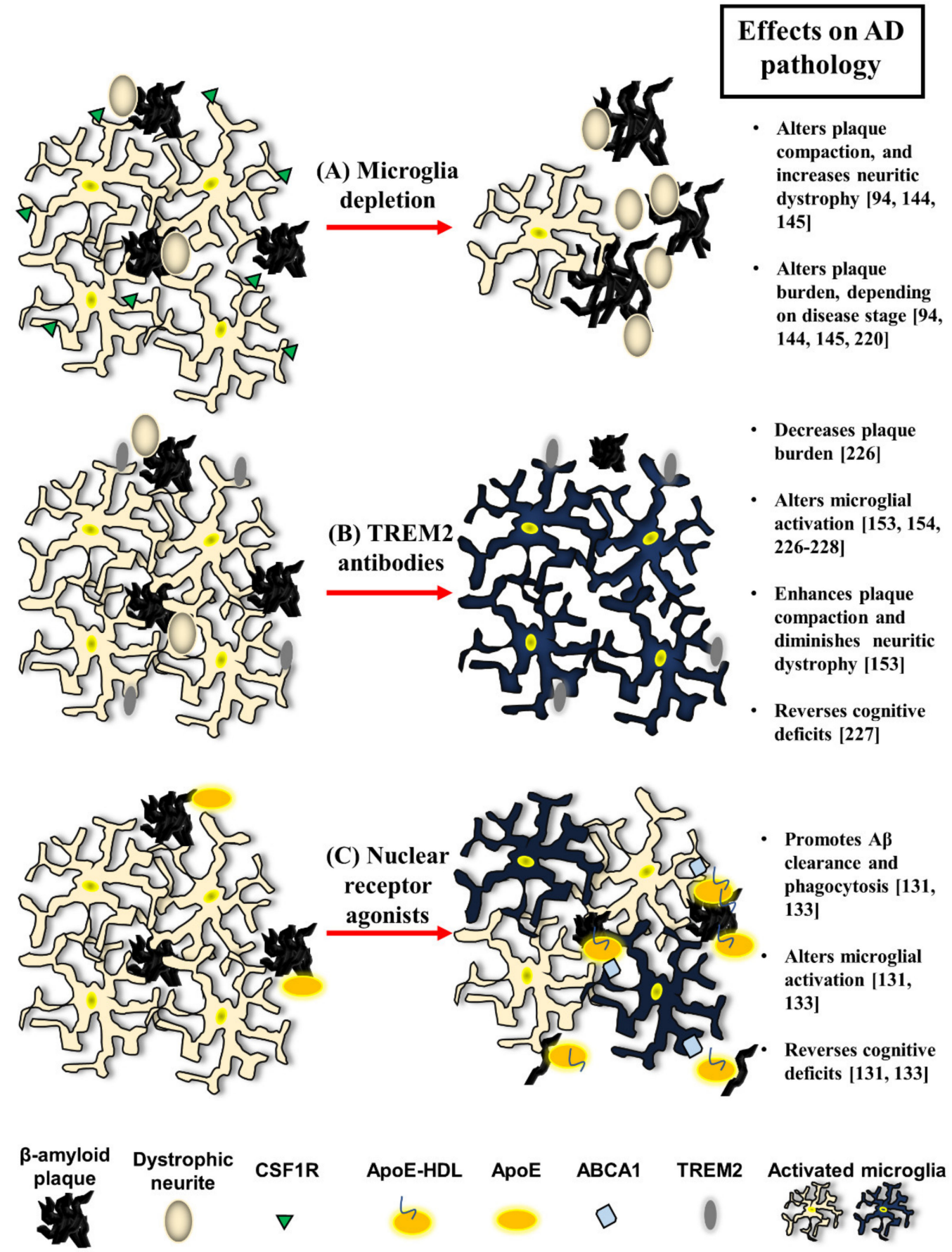

Figure 2. Microglia-directed manipulations and therapeutics modify pathology in AD. Microglia can be targeted through three generalized paradigms. (A) In microglia depletion models, CSF1R inhibitors kill microglia. Depletion can alter plaque compaction, enhance neuritic dystrophy and modify plaque burden depending on the disease stage. (B) TREM2 antibodies have been shown to promote microglial activation profiles amenable to phagocytosing plaques, enhancing plaque compaction, abrogating neuritic dystrophy and ameliorating cognition. (C) Nuclear receptor agonists promote upregulation of lipoprotein ApoE, its lipid transporter ABCA1 and production of ApoE-HDLs, the former of which promotes A $\beta$ clearance by microglia. Nuclear receptors also enhance $A \beta$ phagocytosis, alter microglia polarization and reverse cognitive deficits in various mouse models of AD. In this figure, references are denoted after the effects on AD pathology of each paradigm. 


\subsection{Usage of Nuclear Receptor Agonists to Target Microglia}

There is substantial literature demonstrating the salutary actions of therapeutics in $\mathrm{AD}$ mouse models. In particular, nuclear receptor agonists drive the transcription of genes associated with $\mathrm{A} \beta$ clearance and phagocytosis, and the modulation of inflammation in various mouse models of $\mathrm{AD}$ [131]. The nuclear receptor superfamily is composed of hundreds of receptors expressed ubiquitously in mammalian tissues [229]. One class of nuclear receptors form heterodimers exclusively with the retinoid $X$ receptor (RXR). These RXR-heterodimers reside on DNA in the nucleus tethered to co-repressor proteins; once respective ligands bind, co-repressor proteins are exchanged with co-activator proteins, initiating target gene transcription [131]. As heterodimers with RXR, liver X receptors (LXRs) and peroxisome proliferator-activated receptors (PPARs) both activate genes associated with $A \beta$ clearance, phagocytosis and the resolution of inflammation [133]. In various AD mouse models, nuclear receptor agonists broadly ameliorate AD pathology as well as rescue cognitive and behavioral deficits [131]. LXR activation promotes the upregulation of ApoE as well as its lipid transporters ABCA1 and ABCG1, leading to the formation of ApoE-HDL particles. In astrocytes and microglia, ApoE-HDLs promote the degradation and clearance of soluble $A \beta$ [132]. Inflammatory signaling is also dampened, since nuclear receptors promote the transrepression of pro-inflammatory cytokines, such as IL-6 and $\mathrm{TNF} \alpha$, in AD mice and in microglia specifically [230-234]. PPAR signaling activates genes associated with lipid clearance, including $L p l$ and CD36. Phagocytic protein machinery molecules, such as A $\beta$-binding scavenger receptor CD36 [140], and phagocytic-like receptors such as MerTK or TREM2 [141,235], can also be induced via activation of nuclear receptor signaling (Figure $2 \mathrm{C}$ ).

It should be noted that the salutary actions of nuclear receptor agonists in AD or homeostasis occur through other glia, and even directly in neurons as well [131,133,236,237]. Although nuclear receptor agonists act on all cell types of the brain, microglia preferentially express a broad repertoire of processes amenable to nuclear receptor agonist action [238]. Some markers of the DAM/MGnD phenotype that are responsible for lipid clearance are direct target genes of PPAR (e.g., $\mathrm{Lpl}$ ) or LXR (e.g., Apoe), pointing to their collective importance in regulating microglial homeostasis during AD [239]. Interestingly, plaque-associated ApoE is largely sourced to microglia [185], but astrocytes are also proficient producers of ApoE during steady-state [240]. The overall impact of glial-specific (e.g., microglia or astrocytes) nuclear receptor signaling on AD pathology has yet to be demonstrated. This distinction may be critical going forward to develop therapeutics specific to microglia in both the AD and neurodegenerative disease arena.

\section{Conclusions}

In this review, we focused on the importance of microglia during homeostasis and neurodegenerative diseases, with particular focus on their functions during AD. The recent advances in ontological tracing and single-cell sequencing have rapidly expanded our understanding of microglial biology during development and disease. Microglia-specific receptors play key roles during $\mathrm{AD}$ progression, along with inflammatory mediators present on or released by microglia. In humans and in mouse models, DAM/MGnD phenotypes are broadly manifested across neurodegenerative landscapes, but it is unclear whether scientists and clinicians can exploit these cells to ameliorate disease with targeted therapeutics or other means. Although monocytes are rarely trafficked into the brain in $\mathrm{AD}$ mouse models, clearer evidence now exists concerning myeloid cells at the brain borders. As such, their similarities to microglia should not be ignored when considering the progression of neurodegenerative disorders. In concert, the pathological roles microglia play during $\mathrm{AD}$ are complex, and several questions remain unanswered. Nonetheless, microglia or their specialized functions as immune cells can be targeted with various therapeutics, leaving scientists with several means to uncover how these unique cells contribute to and regulate the homeostatic and disease processes of the CNS. 
Author Contributions: B.T.C. and E.G.R.-G. conceptualized, wrote and edited the manuscript. All authors have read and agreed to the published version of the manuscript.

Funding: This work was supported by institutional funds (E.G.R.-G.).

Institutional Review Board Statement: Not applicable.

Informed Consent Statement: Not applicable.

Data Availability Statement: Not applicable.

Conflicts of Interest: The authors declare no conflict of interest exist.

\section{References}

1. Ginhoux, F.; Greter, M.; Leboeuf, M.; Nandi, S.; See, P.; Gokhan, S.; Mehler, M.F.; Conway, S.J.; Ng, L.G.; Stanley, E.R.; et al. Fate Mapping Analysis Reveals That Adult Microglia Derive from Primitive Macrophages. Science 2010, 330, 841-845. [CrossRef]

2. Xu, J.; Zhu, L.; He, S.; Wu, Y.; Jin, W.; Yu, T.; Qu, J.Y.; Wen, Z. Temporal-Spatial Resolution Fate Mapping Reveals Distinct Origins for Embryonic and Adult Microglia in Zebrafish. Dev. Cell 2015, 34, 632-641. [CrossRef] [PubMed]

3. Gomez Perdiguero, E.; Klapproth, K.; Schulz, C.; Busch, K.; Azzoni, E.; Crozet, L.; Garner, H.; Trouillet, C.; de Bruijn, M.F.; Geissmann, F.; et al. Tissue-Resident Macrophages Originate from Yolk-Sac-Derived Erythro-Myeloid Progenitors. Nature 2015, 518, 547-551. [CrossRef]

4. Hoeffel, G.; Chen, J.; Lavin, Y.; Low, D.; Almeida, F.F.; See, P.; Beaudin, A.E.; Lum, J.; Low, I.; Forsberg, E.C.; et al. C-Myb+ ErythroMyeloid Progenitor-Derived Fetal Monocytes Give Rise to Adult Tissue-Resident Macrophages. Immunity 2015, 42, 665-678. [CrossRef]

5. Schulz, C.; Gomez Perdiguero, E.; Chorro, L.; Szabo-Rogers, H.; Cagnard, N.; Kierdorf, K.; Prinz, M.; Wu, B.; Jacobsen, S.E.W.; Pollard, J.W.; et al. A Lineage of Myeloid Cells Independent of Myb and Hematopoietic Stem Cells. Science 2012, 336, 86-90. [CrossRef] [PubMed]

6. Kierdorf, K.; Erny, D.; Goldmann, T.; Sander, V.; Schulz, C.; Perdiguero, E.G.; Wieghofer, P.; Heinrich, A.; Riemke, P.; Hölscher, C.; et al. Microglia Emerge from Erythromyeloid Precursors via Pu.1- and Irf8-Dependent Pathways. Nat. Neurosci. 2013, 16, 273-280. [CrossRef] [PubMed]

7. Buttgereit, A.; Lelios, I.; Yu, X.; Vrohlings, M.; Krakoski, N.R.; Gautier, E.L.; Nishinakamura, R.; Becher, B.; Greter, M. Sall1 Is a Transcriptional Regulator Defining Microglia Identity and Function. Nat. Immunol. 2016, 17, 1397-1406. [CrossRef] [PubMed]

8. Matcovitch-Natan, O.; Winter, D.R.; Giladi, A.; Aguilar, S.V.; Spinrad, A.; Sarrazin, S.; Ben-Yehuda, H.; David, E.; González, F.Z.; Perrin, P.; et al. Microglia Development Follows a Stepwise Program to Regulate Brain Homeostasis. Science 2016. [CrossRef]

9. Wang, Y.; Szretter, K.J.; Vermi, W.; Gilfillan, S.; Rossini, C.; Cella, M.; Barrow, A.D.; Diamond, M.S.; Colonna, M. IL-34 Is a Tissue-Restricted Ligand of CSF1R Required for the Development of Langerhans Cells and Microglia. Nat. Immunol. 2012, 13, 753-760. [CrossRef]

10. Erny, D.; Hrabě de Angelis, A.L.; Jaitin, D.; Wieghofer, P.; Staszewski, O.; David, E.; Keren-Shaul, H.; Mahlakoiv, T.; Jakobshagen, K.; Buch, T.; et al. Host Microbiota Constantly Control Maturation and Function of Microglia in the CNS. Nat. Neurosci. 2015, 18, 965-977. [CrossRef]

11. Thion, M.S.; Low, D.; Silvin, A.; Chen, J.; Grisel, P.; Schulte-Schrepping, J.; Blecher, R.; Ulas, T.; Squarzoni, P.; Hoeffel, G.; et al. Microbiome Influences Prenatal and Adult Microglia in a Sex-Specific Manner. Cell 2018, 172, 500-516. [CrossRef]

12. Butovsky, O.; Jedrychowski, M.P.; Moore, C.S.; Cialic, R.; Lanser, A.J.; Gabriely, G.; Koeglsperger, T.; Dake, B.; Wu, P.M.; Doykan, C.E.; et al. Identification of a Unique TGF- $\beta$ Dependent Molecular and Functional Signature in Microglia. Nat. Neurosci. 2014, 17, 131-143. [CrossRef] [PubMed]

13. Bruttger, J.; Karram, K.; Wörtge, S.; Regen, T.; Marini, F.; Hoppmann, N.; Klein, M.; Blank, T.; Yona, S.; Wolf, Y.; et al. Genetic Cell Ablation Reveals Clusters of Local Self-Renewing Microglia in the Mammalian Central Nervous System. Immunity 2015, 43, 92-106. [CrossRef]

14. Cronk, J.C.; Filiano, A.J.; Louveau, A.; Marin, I.; Marsh, R.; Ji, E.; Goldman, D.H.; Smirnov, I.; Geraci, N.; Acton, S.; et al. Peripherally Derived Macrophages Can Engraft the Brain Independent of Irradiation and Maintain an Identity Distinct from Microglia. J. Exp. Med. 2018, 215, 1627-1647. [CrossRef] [PubMed]

15. Füger, P.; Hefendehl, J.K.; Veeraraghavalu, K.; Wendeln, A.-C.; Schlosser, C.; Obermüller, U.; Wegenast-Braun, B.M.; Neher, J.J.; Martus, P.; Kohsaka, S.; et al. Microglia Turnover with Aging and in an Alzheimer's Model via Long-Term in Vivo Single-Cell Imaging. Nat. Neurosci. 2017, 20, 1371-1376. [CrossRef]

16. Tay, T.L.; Mai, D.; Dautzenberg, J.; Fernandez-Klett, F.; Lin, G.; Datta, M.; Drougard, A.; Stempfl, T.; Ardura-Fabregat, A.; Staszewski, O.; et al. A New Fate Mapping System Reveals Context-Dependent Random or Clonal Expansion of Microglia. Nat. Neurosci. 2017, 20, 793-803. [CrossRef]

17. Li, Q.; Barres, B.A. Microglia and Macrophages in Brain Homeostasis and Disease. Nat. Rev. Immunol. 2018, 18, $225-242$. [CrossRef] [PubMed]

18. Schafer, D.P.; Stevens, B. Microglia Function in Central Nervous System Development and Plasticity. Cold Spring Harb. Perspect. Biol. 2015, 7. [CrossRef] 
19. Liddelow, S.A.; Barres, B.A. Reactive Astrocytes: Production, Function, and Therapeutic Potential. Immunity 2017, 46, 957-967. [CrossRef]

20. Stevens, B.; Allen, N.J.; Vazquez, L.E.; Howell, G.R.; Christopherson, K.S.; Nouri, N.; Micheva, K.D.; Mehalow, A.K.; Huberman, A.D.; Stafford, B.; et al. The Classical Complement Cascade Mediates CNS Synapse Elimination. Cell 2007, 131, 1164-1178. [CrossRef]

21. Schafer, D.P.; Lehrman, E.K.; Kautzman, A.G.; Koyama, R.; Mardinly, A.R.; Yamasaki, R.; Ransohoff, R.M.; Greenberg, M.E.; Barres, B.A.; Stevens, B. Microglia Sculpt Postnatal Neural Circuits in an Activity and Complement-Dependent Manner. Neuron 2012, 74, 691-705. [CrossRef]

22. Brown, G.C.; Neher, J.J. Microglial Phagocytosis of Live Neurons. Nat. Rev. Neurosci. 2014, 15, 209-216. [CrossRef] [PubMed]

23. Lehrman, E.K.; Wilton, D.K.; Litvina, E.Y.; Welsh, C.A.; Chang, S.T.; Frouin, A.; Walker, A.J.; Heller, M.D.; Umemori, H.; Chen, C.; et al. CD47 Protects Synapses from Excess Microglia-Mediated Pruning during Development. Neuron 2018, 100, 120-134. [CrossRef]

24. Liu, L.; Liu, J.; Bao, J.; Bai, Q.; Wang, G. Interaction of Microglia and Astrocytes in the Neurovascular Unit. Front. Immunol. 2020, 11. [CrossRef]

25. Grossmann, R.; Stence, N.; Carr, J.; Fuller, L.; Waite, M.; Dailey, M.E. Juxtavascular Microglia Migrate along Brain Microvessels Following Activation during Early Postnatal Development. Glia 2002, 37, 229-240. [CrossRef]

26. Mondo, E.; Becker, S.C.; Kautzman, A.G.; Schifferer, M.; Baer, C.E.; Chen, J.; Huang, E.J.; Simons, M.; Schafer, D.P. A Developmental Analysis of Juxtavascular Microglia Dynamics and Interactions with the Vasculature. J. Neurosci. 2020, 40, 6503-6521. [CrossRef]

27. Zhao, X.; Eyo, U.B.; Murguan, M.; Wu, L.-J. Microglial Interaction with the Neurovascular System in Physiology and Pathology. Dev. Neurobiol 2018, 78, 604-617. [CrossRef]

28. Han, J.; Zhu, K.; Zhang, X.; Harris, R.A. Enforced Microglial Depletion and Repopulation as a Promising Strategy for the Treatment of Neurological Disorders. Glia 2019, 67, 217-231. [CrossRef]

29. Frost, J.L.; Schafer, D.P. Microglia: Architects of the Developing Nervous System. Trends Cell Biol. 2016, 26, 587-597. [CrossRef] [PubMed]

30. Cunningham, C.L.; Martínez-Cerdeño, V.; Noctor, S.C. Microglia Regulate the Number of Neural Precursor Cells in the Developing Cerebral Cortex. J. Neurosci. 2013, 33, 4216-4233. [CrossRef] [PubMed]

31. Nieto-Estévez, V.; Defterali, Ç.; Vicario-Abejón, C. IGF-I: A Key Growth Factor That Regulates Neurogenesis and Synaptogenesis from Embryonic to Adult Stages of the Brain. Front. Neurosci. 2016, 10. [CrossRef]

32. Li, Q.; Cheng, Z.; Zhou, L.; Darmanis, S.; Neff, N.F.; Okamoto, J.; Gulati, G.; Bennett, M.L.; Sun, L.O.; Clarke, L.E.; et al. Developmental Heterogeneity of Microglia and Brain Myeloid Cells Revealed by Deep Single-Cell RNA Sequencing. Neuron 2019, 101, 207-223. [CrossRef]

33. Wlodarczyk, A.; Holtman, I.R.; Krueger, M.; Yogev, N.; Bruttger, J.; Khorooshi, R.; Benmamar-Badel, A.; de Boer-Bergsma, J.J.; Martin, N.A.; Karram, K.; et al. A Novel Microglial Subset Plays a Key Role in Myelinogenesis in Developing Brain. EMBO J. 2017, 36, 3292-3308. [CrossRef] [PubMed]

34. Safaiyan, S.; Besson-Girard, S.; Kaya, T.; Cantuti-Castelvetri, L.; Liu, L.; Ji, H.; Schifferer, M.; Gouna, G.; Usifo, F.; Kannaiyan, N.; et al. White Matter Aging Drives Microglial Diversity. Neuron 2021. [CrossRef] [PubMed]

35. Hagemeyer, N.; Hanft, K.-M.; Akriditou, M.-A.; Unger, N.; Park, E.S.; Stanley, E.R.; Staszewski, O.; Dimou, L.; Prinz, M. Microglia Contribute to Normal Myelinogenesis and to Oligodendrocyte Progenitor Maintenance during Adulthood. Acta Neuropathol. 2017, 134, 441-458. [CrossRef] [PubMed]

36. Zöller, T.; Schneider, A.; Kleimeyer, C.; Masuda, T.; Potru, P.S.; Pfeifer, D.; Blank, T.; Prinz, M.; Spittau, B. Silencing of TGF $\beta$ Signalling in Microglia Results in Impaired Homeostasis. Nat. Commun. 2018, 9, 4011. [CrossRef] [PubMed]

37. Bialas, A.R.; Stevens, B. TGF- $\beta$ Signaling Regulates Neuronal C1q Expression and Developmental Synaptic Refinement. Nat. Neurosci. 2013, 16, 1773-1782. [CrossRef]

38. Parkhurst, C.N.; Yang, G.; Ninan, I.; Savas, J.N.; Yates, J.R.; Lafaille, J.J.; Hempstead, B.L.; Littman, D.R.; Gan, W.-B. Microglia Promote Learning-Dependent Synapse Formation through Brain-Derived Neurotrophic Factor. Cell 2013, 155, 1596-1609. [CrossRef]

39. Badimon, A.; Strasburger, H.J.; Ayata, P.; Chen, X.; Nair, A.; Ikegami, A.; Hwang, P.; Chan, A.T.; Graves, S.M.; Uweru, J.O.; et al. Negative Feedback Control of Neuronal Activity by Microglia. Nature 2020, 586, 417-423. [CrossRef]

40. Lloyd, A.F.; Miron, V.E. The Pro-Remyelination Properties of Microglia in the Central Nervous System. Nat. Rev. Neurol. 2019, 15, 447-458. [CrossRef] [PubMed]

41. Miron, V.E.; Boyd, A.; Zhao, J.-W.; Yuen, T.J.; Ruckh, J.M.; Shadrach, J.L.; van Wijngaarden, P.; Wagers, A.J.; Williams, A.; Franklin, R.J.M.; et al. M2 Microglia and Macrophages Drive Oligodendrocyte Differentiation during CNS Remyelination. Nat. Neurosci. 2013, 16, 1211-1218. [CrossRef]

42. Jay, T.R.; von Saucken, V.E.; Muñoz, B.; Codocedo, J.F.; Atwood, B.K.; Lamb, B.T.; Landreth, G.E. TREM2 Is Required for Microglial Instruction of Astrocytic Synaptic Engulfment in Neurodevelopment. Glia 2019, 67, 1873-1892. [CrossRef] [PubMed]

43. Filipello, F.; Morini, R.; Corradini, I.; Zerbi, V.; Canzi, A.; Michalski, B.; Erreni, M.; Markicevic, M.; Starvaggi-Cucuzza, C.; Otero, K.; et al. The Microglial Innate Immune Receptor TREM2 Is Required for Synapse Elimination and Normal Brain Connectivity. Immunity 2018, 48, 979-991. [CrossRef] 
44. Vainchtein, I.D.; Chin, G.; Cho, F.S.; Kelley, K.W.; Miller, J.G.; Chien, E.C.; Liddelow, S.A.; Nguyen, P.T.; Nakao-Inoue, H.; Dorman, L.C.; et al. Astrocyte-Derived Interleukin-33 Promotes Microglial Synapse Engulfment and Neural Circuit Development. Science 2018, 359, 1269-1273. [CrossRef] [PubMed]

45. Wang, C.; Yue, H.; Hu, Z.; Shen, Y.; Ma, J.; Li, J.; Wang, X.-D.; Wang, L.; Sun, B.; Shi, P.; et al. Microglia Mediate Forgetting via Complement-Dependent Synaptic Elimination. Science 2020, 367, 688-694. [CrossRef] [PubMed]

46. Paolicelli, R.C.; Bolasco, G.; Pagani, F.; Maggi, L.; Scianni, M.; Panzanelli, P.; Giustetto, M.; Ferreira, T.A.; Guiducci, E.; Dumas, L.; et al. Synaptic Pruning by Microglia Is Necessary for Normal Brain Development. Science 2011, 333, 1456-1458. [CrossRef]

47. Cardona, A.E.; Pioro, E.P.; Sasse, M.E.; Kostenko, V.; Cardona, S.M.; Dijkstra, I.M.; Huang, D.; Kidd, G.; Dombrowski, S.; Dutta, R.; et al. Control of Microglial Neurotoxicity by the Fractalkine Receptor. Nat. Neurosci. 2006, 9, 917-924. [CrossRef]

48. Rogers, J.T.; Morganti, J.M.; Bachstetter, A.D.; Hudson, C.E.; Peters, M.M.; Grimmig, B.A.; Weeber, E.J.; Bickford, P.C.; Gemma, C. CX3CR1 Deficiency Leads to Impairment of Hippocampal Cognitive Function and Synaptic Plasticity. J. Neurosci. 2011, 31, 16241-16250. [CrossRef]

49. Ueno, M.; Fujita, Y.; Tanaka, T.; Nakamura, Y.; Kikuta, J.; Ishii, M.; Yamashita, T. Layer V Cortical Neurons Require Microglial Support for Survival during Postnatal Development. Nat. Neurosci. 2013, 16, 543-551. [CrossRef]

50. Condello, C.; Yuan, P.; Schain, A.; Grutzendler, J. Microglia Constitute a Barrier That Prevents Neurotoxic Protofibrillar A $\beta 42$ Hotspots around Plaques. Nat. Commun. 2015, 6, 6176. [CrossRef]

51. Keren-Shaul, H.; Spinrad, A.; Weiner, A.; Matcovitch-Natan, O.; Dvir-Szternfeld, R.; Ulland, T.K.; David, E.; Baruch, K.; Lara-Astaiso, D.; Toth, B.; et al. A Unique Microglia Type Associated with Restricting Development of Alzheimer's Disease. Cell 2017, 169, 1276-1290. [CrossRef]

52. Krasemann, S.; Madore, C.; Cialic, R.; Baufeld, C.; Calcagno, N.; El Fatimy, R.; Beckers, L.; O'Loughlin, E.; Xu, Y.; Fanek, Z.; et al. The TREM2-APOE Pathway Drives the Transcriptional Phenotype of Dysfunctional Microglia in Neurodegenerative Diseases. Immunity 2017, 47, 566-581. [CrossRef]

53. Haynes, S.E.; Hollopeter, G.; Yang, G.; Kurpius, D.; Dailey, M.E.; Gan, W.-B.; Julius, D. The P2Y12 Receptor Regulates Microglial Activation by Extracellular Nucleotides. Nat. Neurosci. 2006, 9, 1512-1519. [CrossRef]

54. Cserép, C.; Pósfai, B.; Lénárt, N.; Fekete, R.; László, Z.I.; Lele, Z.; Orsolits, B.; Molnár, G.; Heindl, S.; Schwarcz, A.D.; et al. Microglia Monitor and Protect Neuronal Function through Specialized Somatic Purinergic Junctions. Science 2020, 367, 528-537. [CrossRef]

55. Peng, J.; Liu, Y.; Umpierre, A.D.; Xie, M.; Tian, D.-S.; Richardson, J.R.; Wu, L.-J. Microglial P2Y12 Receptor Regulates Ventral Hippocampal CA1 Neuronal Excitability and Innate Fear in Mice. Mol. Brain 2019, 12. [CrossRef] [PubMed]

56. Yeh, F.L.; Wang, Y.; Tom, I.; Gonzalez, L.C.; Sheng, M. TREM2 Binds to Apolipoproteins, Including APOE and CLU/APOJ, and Thereby Facilitates Uptake of Amyloid-Beta by Microglia. Neuron 2016, 91, 328-340. [CrossRef] [PubMed]

57. Zhao, Y.; Wu, X.; Li, X.; Jiang, L.-L.; Gui, X.; Liu, Y.; Sun, Y.; Zhu, B.; Piña-Crespo, J.C.; Zhang, M.; et al. TREM2 Is a Receptor for $\beta$-Amyloid That Mediates Microglial Function. Neuron 2018, 97, 1023-1031. [CrossRef] [PubMed]

58. Wang, Y.; Cella, M.; Mallinson, K.; Ulrich, J.D.; Young, K.L.; Robinette, M.L.; Gilfillan, S.; Krishnan, G.M.; Sudhakar, S.; Zinselmeyer, B.H.; et al. TREM2 Lipid Sensing Sustains the Microglial Response in an Alzheimer's Disease Model. Cell 2015, 160, 1061-1071. [CrossRef] [PubMed]

59. Mazaheri, F.; Snaidero, N.; Kleinberger, G.; Madore, C.; Daria, A.; Werner, G.; Krasemann, S.; Capell, A.; Trümbach, D.; Wurst, W.; et al. TREM2 Deficiency Impairs Chemotaxis and Microglial Responses to Neuronal Injury. EMBO Rep. 2017, 18, 1186-1198. [CrossRef] [PubMed]

60. Ulland, T.K.; Colonna, M. TREM2-A Key Player in Microglial Biology and Alzheimer Disease. Nat. Rev. Neurol. 2018, 14, 667-675. [CrossRef]

61. Yuan, P.; Condello, C.; Keene, C.D.; Wang, Y.; Bird, T.D.; Paul, S.M.; Luo, W.; Colonna, M.; Baddeley, D.; Grutzendler, J. TREM2 Haplodeficiency in Mice and Humans Impairs the Microglia Barrier Function Leading to Decreased Amyloid Compaction and Severe Axonal Dystrophy. Neuron 2016, 90, 724-739. [CrossRef]

62. Cheng-Hathaway, P.J.; Reed-Geaghan, E.G.; Jay, T.R.; Casali, B.T.; Bemiller, S.M.; Puntambekar, S.S.; von Saucken, V.E.; Williams, R.Y.; Karlo, J.C.; Moutinho, M.; et al. The Trem2 R47H Variant Confers Loss-of-Function-like Phenotypes in Alzheimer's Disease. Mol. Neurodegener 2018, 13. [CrossRef]

63. Stanley, E.R.; Chitu, V. CSF-1 Receptor Signaling in Myeloid Cells. Cold Spring Harb. Perspect. Biol. 2014, 6. [CrossRef]

64. Chitu, V.; Gokhan, S.; Nandi, S.; Mehler, M.F.; Stanley, E.R. Emerging Roles for CSF-1 Receptor and Its Ligands in the Nervous System. Trends Neurosci. 2016, 39, 378-393. [CrossRef]

65. Erblich, B.; Zhu, L.; Etgen, A.M.; Dobrenis, K.; Pollard, J.W. Absence of Colony Stimulation Factor-1 Receptor Results in Loss of Microglia, Disrupted Brain Development and Olfactory Deficits. PLoS ONE 2011, 6. [CrossRef] [PubMed]

66. Greter, M.; Lelios, I.; Pelczar, P.; Hoeffel, G.; Price, J.; Leboeuf, M.; Kündig, T.M.; Frei, K.; Ginhoux, F.; Merad, M.; et al. StromaDerived Interleukin-34 Controls the Development and Maintenance of Langerhans Cells and the Maintenance of Microglia. Immunity 2012, 37, 1050-1060. [CrossRef] [PubMed]

67. Luo, J.; Elwood, F.; Britschgi, M.; Villeda, S.; Zhang, H.; Ding, Z.; Zhu, L.; Alabsi, H.; Getachew, R.; Narasimhan, R.; et al. Colony-Stimulating Factor 1 Receptor (CSF1R) Signaling in Injured Neurons Facilitates Protection and Survival. J. Exp. Med. 2013, 210, 157-172. [CrossRef] [PubMed] 
68. Martin-Estebane, M.; Gomez-Nicola, D. Targeting Microglial Population Dynamics in Alzheimer's Disease: Are We Ready for a Potential Impact on Immune Function? Front. Cell. Neurosci. 2020, 14. [CrossRef]

69. Koeglsperger, T.; Li, S.; Brenneis, C.; Saulnier, J.L.; Mayo, L.; Carrier, Y.; Selkoe, D.J.; Weiner, H.L. Impaired Glutamate Recycling and GluN2B-Mediated Neuronal Calcium Overload in Mice Lacking TGF-B1 in the CNS. Glia 2013, 61, 985-1002. [CrossRef] [PubMed]

70. Hong, S.; Beja-Glasser, V.F.; Nfonoyim, B.M.; Frouin, A.; Li, S.; Ramakrishnan, S.; Merry, K.M.; Shi, Q.; Rosenthal, A.; Barres, B.A.; et al. Complement and Microglia Mediate Early Synapse Loss in Alzheimer Mouse Models. Science 2016, 352, 712-716. [CrossRef] [PubMed]

71. Liddelow, S.A.; Guttenplan, K.A.; Clarke, L.E.; Bennett, F.C.; Bohlen, C.J.; Schirmer, L.; Bennett, M.L.; Münch, A.E.; Chung, W.-S.; Peterson, T.C.; et al. Neurotoxic Reactive Astrocytes Are Induced by Activated Microglia. Nature 2017, 541, 481-487. [CrossRef] [PubMed]

72. Langmann, T. Microglia Activation in Retinal Degeneration. J. Leukoc. Biol. 2007, 81, 1345-1351. [CrossRef] [PubMed]

73. Manich, G.; Recasens, M.; Valente, T.; Almolda, B.; González, B.; Castellano, B. Role of the CD200-CD200R Axis During Homeostasis and Neuroinflammation. Neuroscience 2019, 405, 118-136. [CrossRef]

74. Hoek, R.M.; Ruuls, S.R.; Murphy, C.A.; Wright, G.J.; Goddard, R.; Zurawski, S.M.; Blom, B.; Homola, M.E.; Streit, W.J.; Brown, M.H.; et al. Down-Regulation of the Macrophage Lineage through Interaction with OX2 (CD200). Science 2000, 290, 1768-1771. [CrossRef] [PubMed]

75. Zhao, X.; Li, J.; Sun, H. CD200-CD200R Interaction: An Important Regulator After Stroke. Front. Neurosci. 2019, 13. [CrossRef]

76. Biber, K.; Neumann, H.; Inoue, K.; Boddeke, H.W.G.M. Neuronal 'On' and 'Off' Signals Control Microglia. Trends Neurosci. 2007, 30, 596-602. [CrossRef]

77. Walker, D.G.; Dalsing-Hernandez, J.E.; Campbell, N.A.; Lue, L.-F. Decreased Expression of CD200 and CD200 Receptor in Alzheimer's Disease: A Potential Mechanism Leading to Chronic Inflammation. Exp. Neurol. 2009, 215, 5-19. [CrossRef]

78. Lyons, A.; Downer, E.J.; Crotty, S.; Nolan, Y.M.; Mills, K.H.G.; Lynch, M.A. CD200 Ligand-Receptor Interaction Modulates Microglial Activation In Vivo and In Vitro: A Role for IL-4. J. Neurosci. 2007, 27, 8309-8313. [CrossRef]

79. Varnum, M.M.; Kiyota, T.; Ingraham, K.L.; Ikezu, S.; Ikezu, T. The Anti-Inflammatory Glycoprotein, CD200, Restores Neurogenesis and Enhances Amyloid Phagocytosis in a Mouse Model of Alzheimer's Disease. Neurobiol. Aging 2015, 36, 2995-3007. [CrossRef]

80. Kielian, T. Toll-Like Receptors in Central Nervous System Glial Inflammation and Homeostasis. J. Neurosci. Res. 2006, 83, 711-730. [CrossRef]

81. Takeuchi, O.; Akira, S. Pattern Recognition Receptors and Inflammation. Cell 2010, 140, 805-820. [CrossRef]

82. Fassbender, K.; Walter, S.; Kühl, S.; Landmann, R.; Ishii, K.; Bertsch, T.; Stalder, A.K.; Muehlhauser, F.; Liu, Y.; Ulmer, A.J.; et al. The LPS Receptor (CD14) Links Innate Immunity with Alzheimer's Disease. FASEB J. 2004, 18, 203-205. [CrossRef] [PubMed]

83. Walter, S.; Letiembre, M.; Liu, Y.; Heine, H.; Penke, B.; Hao, W.; Bode, B.; Manietta, N.; Walter, J.; Schulz-Schuffer, W.; et al. Role of the Toll-like Receptor 4 in Neuroinflammation in Alzheimer's Disease. Cell Physiol. Biochem. 2007, 20, 947-956. [CrossRef] [PubMed]

84. Reed-Geaghan, E.G.; Savage, J.C.; Hise, A.G.; Landreth, G.E. CD14 and Toll-like Receptors 2 and 4 Are Required for Fibrillar A \{beta\}-Stimulated Microglial Activation. J. Neurosci. 2009, 29, 11982-11992. [CrossRef] [PubMed]

85. Song, M.; Jin, J.; Lim, J.-E.; Kou, J.; Pattanayak, A.; Rehman, J.A.; Kim, H.-D.; Tahara, K.; Lalonde, R.; Fukuchi, K. TLR4 Mutation Reduces Microglial Activation, Increases A $\beta$ Deposits and Exacerbates Cognitive Deficits in a Mouse Model of Alzheimer's Disease. J. Neuroinflamm. 2011, 8, 92. [CrossRef] [PubMed]

86. Finneran, D.J.; Nash, K.R. Neuroinflammation and Fractalkine Signaling in Alzheimer's Disease. J. Neuroinflamm. 2019, 16, 30. [CrossRef]

87. Limatola, C.; Ransohoff, R.M. Modulating Neurotoxicity through CX3CL1/CX3CR1 Signaling. Front. Cell Neurosci. 2014, 8, 229. [CrossRef] [PubMed]

88. Block, M.L.; Zecca, L.; Hong, J.-S. Microglia-Mediated Neurotoxicity: Uncovering the Molecular Mechanisms. Nat. Rev. Neurosci. 2007, 8, 57-69. [CrossRef]

89. Hickman, S.E.; Kingery, N.D.; Ohsumi, T.K.; Borowsky, M.L.; Wang, L.; Means, T.K.; El Khoury, J. The Microglial Sensome Revealed by Direct RNA Sequencing. Nat. Neurosci. 2013, 16, 1896-1905. [CrossRef]

90. McKinsey, G.L.; Lizama, C.O.; Keown-Lang, A.E.; Niu, A.; Santander, N.; Larpthaveesarp, A.; Chee, E.; Gonzalez, F.F.; Arnold, T.D. A New Genetic Strategy for Targeting Microglia in Development and Disease. eLife 2020, 9. [CrossRef]

91. Jay, T.R.; von Saucken, V.E.; Landreth, G.E. TREM2 in Neurodegenerative Diseases. Mol. Neurodegener. 2017, 12, 56. [CrossRef]

92. Konishi, H.; Kiyama, H. Microglial TREM2/DAP12 Signaling: A Double-Edged Sword in Neural Diseases. Front. Cell. Neurosci. 2018, 12. [CrossRef] [PubMed]

93. Jay, T.R.; Miller, C.M.; Cheng, P.J.; Graham, L.C.; Bemiller, S.; Broihier, M.L.; Xu, G.; Margevicius, D.; Karlo, J.C.; Sousa, G.L.; et al. TREM2 Deficiency Eliminates TREM2+ Inflammatory Macrophages and Ameliorates Pathology in Alzheimer's Disease Mouse Models. J. Exp. Med. 2015, 212, 287-295. [CrossRef] [PubMed]

94. Elmore, M.R.P.; Najafi, A.R.; Koike, M.A.; Dagher, N.N.; Spangenberg, E.E.; Rice, R.A.; Kitazawa, M.; Matusow, B.; Nguyen, H.; West, B.L.; et al. CSF1 Receptor Signaling Is Necessary for Microglia Viability, Which Unmasks a Cell That Rapidly Repopulates the Microglia-Depleted Adult Brain. Neuron 2014, 82, 380-397. [CrossRef] [PubMed] 
95. Kondo, Y.; Duncan, I.D. Selective Reduction in Microglia Density and Function in the White Matter of Colony-Stimulating Factor-1-Deficient Mice. J. Neurosci. Res. 2009, 87, 2686-2695. [CrossRef] [PubMed]

96. Butovsky, O.; Weiner, H.L. Microglial Signatures and Their Role in Health and Disease. Nat. Rev. Neurosci. 2018, 19, 622-635. [CrossRef]

97. Marschallinger, J.; Iram, T.; Zardeneta, M.; Lee, S.E.; Lehallier, B.; Haney, M.S.; Pluvinage, J.V.; Mathur, V.; Hahn, O.; Morgens, D.W.; et al. Lipid-Droplet-Accumulating Microglia Represent a Dysfunctional and Proinflammatory State in the Aging Brain. Nat. Neurosci. 2020, 23, 194-208. [CrossRef]

98. Fourgeaud, L.; Través, P.G.; Tufail, Y.; Leal-Bailey, H.; Lew, E.D.; Burrola, P.G.; Callaway, P.; Zagórska, A.; Rothlin, C.V.; Nimmerjahn, A.; et al. TAM Receptors Regulate Multiple Features of Microglial Physiology. Nature 2016, 532, 240-244. [CrossRef]

99. Koenigsknecht, J.; Landreth, G. Microglial Phagocytosis of Fibrillar Beta-Amyloid through a Beta1 Integrin-Dependent Mechanism. J. Neurosci. 2004, 24, 9838-9846. [CrossRef]

100. Cameron, B.; Landreth, G.E. Inflammation, Microglia, and Alzheimer's Disease. Neurobiol. Dis. 2010, 37, 503-509. [CrossRef]

101. Galloway, D.A.; Phillips, A.E.M.; Owen, D.R.J.; Moore, C.S. Phagocytosis in the Brain: Homeostasis and Disease. Front. Immunol. 2019, 10. [CrossRef]

102. Martinez, F.O.; Gordon, S. The M1 and M2 Paradigm of Macrophage Activation: Time for Reassessment. F1000Prime Rep. 2014, 6. [CrossRef] [PubMed]

103. Martinez, F.O.; Helming, L.; Gordon, S. Alternative Activation of Macrophages: An Immunologic Functional Perspective. Annu. Rev. Immunol. 2009, 27, 451-483. [CrossRef] [PubMed]

104. Mosser, D.M.; Edwards, J.P. Exploring the Full Spectrum of Macrophage Activation. Nat. Rev. Immunol. 2008, 8, 958-969. [CrossRef] [PubMed]

105. Ransohoff, R.M. A Polarizing Question: Do M1 and M2 Microglia Exist? Nat. Neurosci. 2016, 19, 987-991. [CrossRef]

106. Bartels, T.; Schepper, S.D.; Hong, S. Microglia Modulate Neurodegeneration in Alzheimer's and Parkinson's Diseases. Science 2020, 370, 66-69. [CrossRef]

107. Rawji, K.S.; Yong, V.W. The Benefits and Detriments of Macrophages/Microglia in Models of Multiple Sclerosis. Available online: https:/ / www.hindawi.com/journals/jir/2013/948976/ (accessed on 6 March 2021).

108. Dickson, D.W. Parkinson's Disease and Parkinsonism: Neuropathology. Cold Spring Harb Perspect. Med. 2012,2 , a009258. [CrossRef]

109. Franceschi, C.; Campisi, J. Chronic Inflammation (Inflammaging) and Its Potential Contribution to Age-Associated Diseases. J. Gerontol. Ser. A 2014, 69, S4-S9. [CrossRef]

110. Franceschi, C.; Garagnani, P.; Vitale, G.; Capri, M.; Salvioli, S. Inflammaging and 'Garb-Aging'. Trends Endocrinol. Metab. 2017, 28, 199-212. [CrossRef]

111. Koellhoffer, E.C.; McCullough, L.D.; Ritzel, R.M. Old Maids: Aging and Its Impact on Microglia Function. Int. J. Mol. Sci. 2017, 18. [CrossRef]

112. Olah, M.; Patrick, E.; Villani, A.-C.; Xu, J.; White, C.C.; Ryan, K.J.; Piehowski, P.; Kapasi, A.; Nejad, P.; Cimpean, M.; et al. A Transcriptomic Atlas of Aged Human Microglia. Nat. Commun. 2018, 9, 539. [CrossRef]

113. Holtman, I.R.; Raj, D.D.; Miller, J.A.; Schaafsma, W.; Yin, Z.; Brouwer, N.; Wes, P.D.; Möller, T.; Orre, M.; Kamphuis, W.; et al. Induction of a Common Microglia Gene Expression Signature by Aging and Neurodegenerative Conditions: A Co-Expression Meta-Analysis. Acta Neuropathol. Commun. 2015, 3, 31. [CrossRef] [PubMed]

114. Ham, S.; Lee, S.-J.V. Advances in Transcriptome Analysis of Human Brain Aging. Exp. Mol. Med. 2020, 52, 1787-1797. [CrossRef] [PubMed]

115. Nissen, J.C. Microglial Function across the Spectrum of Age and Gender. Int. J. Mol. Sci. 2017, 18, 561. [CrossRef] [PubMed]

116. Selkoe, D.J. Alzheimer's Disease. Cold Spring Harb. Perspect. Biol. 2011, 3. [CrossRef] [PubMed]

117. Alzheimer's Disease: Facts and Figures. Available online: https://www.alz.org/alzheimers-dementia/facts-figures (accessed on 16 January 2021).

118. Holtzman, D.M.; Herz, J.; Bu, G. Apolipoprotein E and Apolipoprotein E Receptors: Normal Biology and Roles in Alzheimer Disease. Cold Spring Harb. Perspect. Med. 2012, 2. [CrossRef]

119. Lambert, J.-C.; Ibrahim-Verbaas, C.A.; Harold, D.; Naj, A.C.; Sims, R.; Bellenguez, C.; Jun, G.; DeStefano, A.L.; Bis, J.C.; Beecham, G.W.; et al. Meta-Analysis of 74,046 Individuals Identifies 11 New Susceptibility Loci for Alzheimer's Disease. Nat. Genet. 2013, 45, 1452-1458. [CrossRef] [PubMed]

120. Jones, L.; Holmans, P.A.; Hamshere, M.L.; Harold, D.; Moskvina, V.; Ivanov, D.; Pocklington, A.; Abraham, R.; Hollingworth, P.; Sims, R.; et al. Genetic Evidence Implicates the Immune System and Cholesterol Metabolism in the Aetiology of Alzheimer's Disease. PLoS ONE 2010, 5, e13950. [CrossRef]

121. Griciuc, A.; Patel, S.; Federico, A.N.; Choi, S.H.; Innes, B.J.; Oram, M.K.; Cereghetti, G.; McGinty, D.; Anselmo, A.; Sadreyev, R.I.; et al. TREM2 Acts Downstream of CD33 in Modulating Microglial Pathology in Alzheimer's Disease. Neuron 2019, 103, 820-835. [CrossRef]

122. DeMattos, R.B.; Cirrito, J.R.; Parsadanian, M.; May, P.C.; O’Dell, M.A.; Taylor, J.W.; Harmony, J.A.; Aronow, B.J.; Bales, K.R.; Paul, S.M.; et al. ApoE and Clusterin Cooperatively Suppress Abeta Levels and Deposition: Evidence That ApoE Regulates Extracellular Abeta Metabolism in Vivo. Neuron 2004, 41, 193-202. [CrossRef] 
123. Nelson, A.R.; Sagare, A.P.; Zlokovic, B.V. Role of Clusterin in the Brain Vascular Clearance of Amyloid- $\beta$. Proc. Natl. Acad. Sci. USA 2017, 114, 8681-8682. [CrossRef] [PubMed]

124. Crotti, A.; Sait, H.R.; McAvoy, K.M.; Estrada, K.; Ergun, A.; Szak, S.; Marsh, G.; Jandreski, L.; Peterson, M.; Reynolds, T.L.; et al. BIN1 Favors the Spreading of Tau via Extracellular Vesicles. Sci. Rep. 2019, 9, 9477. [CrossRef] [PubMed]

125. Kim, W.S.; Li, H.; Ruberu, K.; Chan, S.; Elliott, D.A.; Low, J.K.; Cheng, D.; Karl, T.; Garner, B. Deletion of Abca7 Increases Cerebral Amyloid- $\beta$ Accumulation in the J20 Mouse Model of Alzheimer's Disease. J. Neurosci. 2013, 33, 4387-4394. [CrossRef]

126. Guerreiro, R.; Wojtas, A.; Bras, J.; Carrasquillo, M.; Rogaeva, E.; Majounie, E.; Cruchaga, C.; Sassi, C.; Kauwe, J.S.K.; Younkin, S.; et al. TREM2 Variants in Alzheimer's Disease. N. Engl. J. Med. 2013, 368, 117-127. [CrossRef] [PubMed]

127. Jonsson, T.; Stefansson, H.; Steinberg, S.; Jonsdottir, I.; Jonsson, P.V.; Snaedal, J.; Bjornsson, S.; Huttenlocher, J.; Levey, A.I.; Lah, J.J.; et al. Variant of TREM2 Associated with the Risk of Alzheimer's Disease. N. Engl. J. Med. 2013, 368, 107-116. [CrossRef]

128. Courtney, R.; Landreth, G.E. LXR Regulation of Brain Cholesterol: From Development to Disease. Trends Endocrinol. Metab. 2016, 27, 404-414. [CrossRef]

129. Loving, B.A.; Bruce, K.D. Lipid and Lipoprotein Metabolism in Microglia. Front. Physiol. 2020, 11. [CrossRef]

130. Mandrekar, S.; Jiang, Q.; Lee, C.Y.; Koenigsknecht-Talboo, J.; Holtzman, D.M.; Landreth, G.E. Microglia Mediate the Clearance of Soluble Abeta through Fluid Phase Macropinocytosis. J. Neurosci. 2009, 29, 4252-4262. [CrossRef]

131. Skerrett, R.; Malm, T.; Landreth, G. Nuclear Receptors in Neurodegenerative Diseases. Neurobiol. Dis. 2014. [CrossRef] [PubMed]

132. Jiang, Q.; Lee, C.Y.D.; Mandrekar, S.; Wilkinson, B.; Cramer, P.; Zelcer, N.; Mann, K.; Lamb, B.; Willson, T.M.; Collins, J.L.; et al. ApoE Promotes the Proteolytic Degradation of Abeta. Neuron 2008, 58, 681-693. [CrossRef] [PubMed]

133. Moutinho, M.; Landreth, G.E. Therapeutic Potential of Nuclear Receptor Agonists in Alzheimer's Disease. J. Lipid. Res. 2017, 58, 1937-1949. [CrossRef] [PubMed]

134. Huynh, T.-P.V.; Wang, C.; Tran, A.C.; Tabor, G.T.; Mahan, T.E.; Francis, C.M.; Finn, M.B.; Spellman, R.; Manis, M.; Tanzi, R.E.; et al. Lack of Hepatic ApoE Does Not Influence Early A $\beta$ Deposition: Observations from a New APOE Knock-in Model. Mol. Neurodegener. 2019, 14, 37. [CrossRef] [PubMed]

135. Stewart, C.R.; Stuart, L.M.; Wilkinson, K.; van Gils, J.M.; Deng, J.; Halle, A.; Rayner, K.J.; Boyer, L.; Zhong, R.; Frazier, W.A.; et al. CD36 Ligands Promote Sterile Inflammation through Assembly of a Toll-like Receptor 4 and 6 Heterodimer. Nat. Immunol. 2010, 11, 155-161. [CrossRef]

136. Doens, D.; Fernández, P.L. Microglia Receptors and Their Implications in the Response to Amyloid $\beta$ for Alzheimer's Disease Pathogenesis. J. Neuroinflamm. 2014, 11, 48. [CrossRef]

137. Bamberger, M.E.; Harris, M.E.; McDonald, D.R.; Husemann, J.; Landreth, G.E. A Cell Surface Receptor Complex for Fibrillar Beta-Amyloid Mediates Microglial Activation. J. Neurosci. 2003, 23, 2665-2674. [CrossRef]

138. Fu, R.; Shen, Q.; Xu, P.; Luo, J.J.; Tang, Y. Phagocytosis of Microglia in the Central Nervous System Diseases. Mol. Neurobiol. 2014, 49, 1422-1434. [CrossRef]

139. Koenigsknecht-Talboo, J.; Landreth, G.E. Microglial Phagocytosis Induced by Fibrillar Beta-Amyloid and IgGs Are Differentially Regulated by Proinflammatory Cytokines. J. Neurosci. 2005, 25, 8240-8249. [CrossRef]

140. Yamanaka, M.; Ishikawa, T.; Griep, A.; Axt, D.; Kummer, M.P.; Heneka, M.T. PPARgamma/RXRalpha-Induced and CD36Mediated Microglial Amyloid-Beta Phagocytosis Results in Cognitive Improvement in Amyloid Precursor Protein/Presenilin 1 Mice. J. Neurosci. Off. J. Soc. Neurosci. 2012, 32, 17321-17331. [CrossRef]

141. Savage, J.C.; Jay, T.; Goduni, E.; Quigley, C.; Mariani, M.M.; Malm, T.; Ransohoff, R.M.; Lamb, B.T.; Landreth, G.E. Nuclear Receptors License Phagocytosis by Trem2+ Myeloid Cells in Mouse Models of Alzheimer's Disease. J. Neurosci. 2015, 35, 6532-6543. [CrossRef] [PubMed]

142. Bolmont, T.; Haiss, F.; Eicke, D.; Radde, R.; Mathis, C.A.; Klunk, W.E.; Kohsaka, S.; Jucker, M.; Calhoun, M.E. Dynamics of the Microglial/Amyloid Interaction Indicate a Role in Plaque Maintenance. J. Neurosci. 2008, 28, 4283-4292. [CrossRef] [PubMed]

143. Condello, C.; Yuan, P.; Grutzendler, J. Microglia-Mediated Neuroprotection, TREM2, and Alzheimer's Disease: Evidence From Optical Imaging. Biol. Psychiatry 2018, 83, 377-387. [CrossRef] [PubMed]

144. Spangenberg, E.; Severson, P.L.; Hohsfield, L.A.; Crapser, J.; Zhang, J.; Burton, E.A.; Zhang, Y.; Spevak, W.; Lin, J.; Phan, N.Y.; et al. Sustained Microglial Depletion with CSF1R Inhibitor Impairs Parenchymal Plaque Development in an Alzheimer's Disease Model. Nat. Commun. 2019, 10. [CrossRef] [PubMed]

145. Casali, B.T.; MacPherson, K.P.; Reed-Geaghan, E.G.; Landreth, G.E. Microglia Depletion Rapidly and Reversibly Alters Amyloid Pathology by Modification of Plaque Compaction and Morphologies. Neurobiol. Dis. 2020, 142, 104956. [CrossRef] [PubMed]

146. Hansen, D.V.; Hanson, J.E.; Sheng, M. Microglia in Alzheimer's Disease. J. Cell Biol. 2018, 217, 459-472. [CrossRef] [PubMed]

147. Yang, J.; Fu, Z.; Zhang, X.; Xiong, M.; Meng, L.; Zhang, Z. TREM2 Ectodomain and Its Soluble Form in Alzheimer's Disease. J. Neuroinflamm. 2020, 17, 204. [CrossRef]

148. Fuhrmann, M.; Bittner, T.; Jung, C.K.; Burgold, S.; Page, R.M.; Mitteregger, G.; Haass, C.; LaFerla, F.M.; Kretzschmar, H.; Herms, J. Microglial Cx3cr1 Knockout Prevents Neuron Loss in a Mouse Model of Alzheimer's Disease. Nat. Neurosci. 2010, 13, 411-413. [CrossRef] [PubMed]

149. Lee, S.; Varvel, N.H.; Konerth, M.E.; Xu, G.; Cardona, A.E.; Ransohoff, R.M.; Lamb, B.T. CX3CR1 Deficiency Alters Microglial Activation and Reduces Beta-Amyloid Deposition in Two Alzheimer's Disease Mouse Models. Am. J. Pathol. 2010. [CrossRef]

150. Liu, Z.; Condello, C.; Schain, A.; Harb, R.; Grutzendler, J. CX3CR1 in Microglia Regulates Brain Amyloid Deposition through Selective Protofibrillar Amyloid-Beta Phagocytosis. J. Neurosci. 2010, 30, 17091-17101. [CrossRef] 
151. Bhaskar, K.; Konerth, M.; Kokiko-Cochran, O.N.; Cardona, A.; Ransohoff, R.M.; Lamb, B.T. Regulation of Tau Pathology by the Microglial Fractalkine Receptor. Neuron 2010, 68, 19-31. [CrossRef]

152. Karanfilian, L.; Tosto, M.G.; Malki, K. The Role of TREM2 in Alzheimer's Disease; Evidence from Transgenic Mouse Models. Neurobiol. Aging 2020, 86, 39-53. [CrossRef]

153. Wang, S.; Mustafa, M.; Yuede, C.M.; Salazar, S.V.; Kong, P.; Long, H.; Ward, M.; Siddiqui, O.; Paul, R.; Gilfillan, S.; et al. Anti-Human TREM2 Induces Microglia Proliferation and Reduces Pathology in an Alzheimer's Disease Model. J. Exp. Med. 2020, 217. [CrossRef]

154. Ellwanger, D.C.; Wang, S.; Brioschi, S.; Shao, Z.; Green, L.; Case, R.; Yoo, D.; Weishuhn, D.; Rathanaswami, P.; Bradley, J.; et al. Prior Activation State Shapes the Microglia Response to Antihuman TREM2 in a Mouse Model of Alzheimer's Disease. Proc. Natl. Acad. Sci. USA 2021, 118. [CrossRef]

155. Leyns, C.E.G.; Gratuze, M.; Narasimhan, S.; Jain, N.; Koscal, L.J.; Jiang, H.; Manis, M.; Colonna, M.; Lee, V.M.Y.; Ulrich, J.D.; et al. TREM2 Function Impedes Tau Seeding in Neuritic Plaques. Nat. Neurosci. 2019, 22, 1217-1222. [CrossRef]

156. Gratuze, M.; Leyns, C.E.G.; Sauerbeck, A.D.; St-Pierre, M.-K.; Xiong, M.; Kim, N.; Serrano, J.R.; Tremblay, M.-È; Kummer, T.T.; Colonna, M.; et al. Impact of TREM2 R47H Variant on Tau Pathology-Induced Gliosis and Neurodegeneration. J. Clin. Investig. 2020, 130, 4954-4968. [CrossRef]

157. Zhong, L.; Chen, X.-F.; Wang, T.; Wang, Z.; Liao, C.; Wang, Z.; Huang, R.; Wang, D.; Li, X.; Wu, L.; et al. Soluble TREM2 Induces Inflammatory Responses and Enhances Microglial Survival. J. Exp. Med. 2017, 214, 597-607. [CrossRef]

158. Zhong, L.; Xu, Y.; Zhuo, R.; Wang, T.; Wang, K.; Huang, R.; Wang, D.; Gao, Y.; Zhu, Y.; Sheng, X.; et al. Soluble TREM2 Ameliorates Pathological Phenotypes by Modulating Microglial Functions in an Alzheimer's Disease Model. Nat. Commun. 2019, $10,1365$. [CrossRef]

159. Griciuc, A.; Serrano-Pozo, A.; Parrado, A.R.; Lesinski, A.N.; Asselin, C.N.; Mullin, K.; Hooli, B.; Choi, S.H.; Hyman, B.T.; Tanzi, R.E. Alzheimer's Disease Risk Gene CD33 Inhibits Microglial Uptake of Amyloid Beta. Neuron 2013, 78, 631-643. [CrossRef]

160. Landreth, G.E.; Reed-Geaghan, E.G. Toll-like Receptors in Alzheimer's Disease. Curr. Top. Microbiol. Immunol. 2009, 336, 137-153. [CrossRef] [PubMed]

161. Fiebich, B.L.; Batista, C.R.A.; Saliba, S.W.; Yousif, N.M.; de Oliveira, A.C.P. Role of Microglia TLRs in Neurodegeneration. Front. Cell. Neurosci. 2018, 12. [CrossRef] [PubMed]

162. Stutz, A.; Golenbock, D.T.; Latz, E. Inflammasomes: Too Big to Miss. J. Clin. Investig. 2009, 119, 3502-3511. [CrossRef] [PubMed]

163. Bergsbaken, T.; Fink, S.L.; Cookson, B.T. Pyroptosis: Host Cell Death and Inflammation. Nat. Rev. Microbiol. $2009,7,99-109$. [CrossRef]

164. Venegas, C.; Kumar, S.; Franklin, B.S.; Dierkes, T.; Brinkschulte, R.; Tejera, D.; Vieira-Saecker, A.; Schwartz, S.; Santarelli, F.; Kummer, M.P.; et al. Microglia-Derived ASC Specks Cross-Seed Amyloid- $\beta$ in Alzheimer's Disease. Nature 2017, 552, $355-361$. [CrossRef]

165. Franklin, B.S.; Bossaller, L.; De Nardo, D.; Ratter, J.M.; Stutz, A.; Engels, G.; Brenker, C.; Nordhoff, M.; Mirandola, S.R.; Al-Amoudi, A.; et al. The Adaptor ASC Has Extracellular and "prionoid" Activities That Propagate Inflammation. Nat. Immunol. 2014, 15, 727-737. [CrossRef] [PubMed]

166. Heneka, M.T.; Kummer, M.P.; Stutz, A.; Delekate, A.; Schwartz, S.; Vieira-Saecker, A.; Griep, A.; Axt, D.; Remus, A.; Tzeng, T.C.; et al. NLRP3 Is Activated in Alzheimer's Disease and Contributes to Pathology in APP/PS1 Mice. Nature 2012. [CrossRef] [PubMed]

167. Ising, C.; Venegas, C.; Zhang, S.; Scheiblich, H.; Schmidt, S.V.; Vieira-Saecker, A.; Schwartz, S.; Albasset, S.; McManus, R.M.; Tejera, D.; et al. NLRP3 Inflammasome Activation Drives Tau Pathology. Nature 2019, 575, 669-673. [CrossRef] [PubMed]

168. Song, W.M.; Colonna, M. The Identity and Function of Microglia in Neurodegeneration. Nat. Immunol. 2018, 19, 1048-1058. [CrossRef]

169. Deczkowska, A.; Keren-Shaul, H.; Weiner, A.; Colonna, M.; Schwartz, M.; Amit, I. Disease-Associated Microglia: A Universal Immune Sensor of Neurodegeneration. Cell 2018, 173, 1073-1081. [CrossRef]

170. Dubbelaar, M.L.; Kracht, L.; Eggen, B.J.L.; Boddeke, E.W.G.M. The Kaleidoscope of Microglial Phenotypes. Front. Immunol. 2018, 9. [CrossRef]

171. Van Hove, H.; Martens, L.; Scheyltjens, I.; De Vlaminck, K.; Pombo Antunes, A.R.; De Prijck, S.; Vandamme, N.; De Schepper, S.; Van Isterdael, G.; Scott, C.L.; et al. A Single-Cell Atlas of Mouse Brain Macrophages Reveals Unique Transcriptional Identities Shaped by Ontogeny and Tissue Environment. Nat. Neurosci. 2019, 22, 1021-1035. [CrossRef]

172. Navarro, V.; Sanchez-Mejias, E.; Jimenez, S.; Muñoz-Castro, C.; Sanchez-Varo, R.; Davila, J.C.; Vizuete, M.; Gutierrez, A.; Vitorica, J. Microglia in Alzheimer's Disease: Activated, Dysfunctional or Degenerative. Front. Aging Neurosci. 2018, 10. [CrossRef]

173. van Olst, L.; Verhaege, D.; Franssen, M.; Kamermans, A.; Roucourt, B.; Carmans, S.; Ytebrouck, E.; van der Pol, S.M.A.; Wever, D.; Popovic, M.; et al. Microglial Activation Arises after Aggregation of Phosphorylated-Tau in a Neuron-Specific P301S Tauopathy Mouse Model. Neurobiol. Aging 2020, 89, 89-98. [CrossRef]

174. Chiu, I.M.; Morimoto, E.T.A.; Goodarzi, H.; Liao, J.T.; O'Keeffe, S.; Phatnani, H.P.; Muratet, M.; Carroll, M.C.; Levy, S.; Tavazoie, S.; et al. A Neurodegeneration-Specific Gene-Expression Signature of Acutely Isolated Microglia from an Amyotrophic Lateral Sclerosis Mouse Model. Cell Rep. 2013, 4, 385-401. [CrossRef] 
175. Lund, H.; Pieber, M.; Parsa, R.; Grommisch, D.; Ewing, E.; Kular, L.; Han, J.; Zhu, K.; Nijssen, J.; Hedlund, E.; et al. Fatal Demyelinating Disease Is Induced by Monocyte-Derived Macrophages in the Absence of TGF- $\beta$ Signaling. Nat. Immunol. 2018, 19, 1-7. [CrossRef]

176. Abutbul, S.; Shapiro, J.; Szaingurten-Solodkin, I.; Levy, N.; Carmy, Y.; Baron, R.; Jung, S.; Monsonego, A. TGF- $\beta$ Signaling through SMAD2/3 Induces the Quiescent Microglial Phenotype within the CNS Environment. Glia 2012, 60, 1160-1171. [CrossRef] [PubMed]

177. Anderson, K.L.; Smith, K.A.; Conners, K.; McKercher, S.R.; Maki, R.A.; Torbett, B.E. Myeloid Development Is Selectively Disrupted in PU.1 Null Mice. Blood 1998, 91, 3702-3710. [CrossRef] [PubMed]

178. Gosselin, D.; Link, V.M.; Romanoski, C.E.; Fonseca, G.J.; Eichenfield, D.Z.; Spann, N.J.; Stender, J.D.; Chun, H.B.; Garner, H.; Geissmann, F; i et al. Environment Drives Selection and Function of Enhancers Controlling Tissue-Specific Macrophage Identities. Cell 2014, 159, 1327-1340. [CrossRef]

179. Gosselin, D.; Skola, D.; Coufal, N.G.; Holtman, I.R.; Schlachetzki, J.C.M.; Sajti, E.; Jaeger, B.N.; O'Connor, C.; Fitzpatrick, C.; Pasillas, M.P.; et al. An Environment-Dependent Transcriptional Network Specifies Human Microglia Identity. Science 2017, 356. [CrossRef] [PubMed]

180. Kim, J.; Basak, J.M.; Holtzman, D.M. The Role of Apolipoprotein E in Alzheimer's Disease. Neuron 2009, 63, 287-303. [CrossRef]

181. Lee, C.Y.D.; Daggett, A.; Gu, X.; Jiang, L.-L.; Langfelder, P.; Li, X.; Wang, N.; Zhao, Y.; Park, C.S.; Cooper, Y.; et al. Elevated TREM2 Gene Dosage Reprograms Microglia Responsivity and Ameliorates Pathological Phenotypes in Alzheimer's Disease Models. Neuron 2018, 97, 1032-1048. [CrossRef] [PubMed]

182. Atagi, Y.; Liu, C.-C.; Painter, M.M.; Chen, X.-F.; Verbeeck, C.; Zheng, H.; Li, X.; Rademakers, R.; Kang, S.S.; Xu, H.; et al. Apolipoprotein E Is a Ligand for Triggering Receptor Expressed on Myeloid Cells 2 (TREM2). J. Biol. Chem. 2015, 290, 26043-26050. [CrossRef] [PubMed]

183. Liu, C.-C.; Zhao, N.; Fu, Y.; Wang, N.; Linares, C.; Tsai, C.-W.; Bu, G. ApoE4 Accelerates Early Seeding of Amyloid Pathology. Neuron 2017, 96, 1024-1032. [CrossRef]

184. Ulrich, J.D.; Ulland, T.K.; Mahan, T.E.; Nyström, S.; Nilsson, K.P.; Song, W.M.; Zhou, Y.; Reinartz, M.; Choi, S.; Jiang, H.; et al. ApoE Facilitates the Microglial Response to Amyloid Plaque Pathology. J. Exp. Med. 2018, 215, 1047-1058. [CrossRef] [PubMed]

185. Parhizkar, S.; Arzberger, T.; Brendel, M.; Kleinberger, G.; Deussing, M.; Focke, C.; Nuscher, B.; Xiong, M.; Ghasemigharagoz, A.; Katzmarski, N.; et al. Loss of TREM2 Function Increases Amyloid Seeding but Reduces Plaque-Associated ApoE. Nat. Neurosci. 2019, 22, 191-204. [CrossRef] [PubMed]

186. Prinz, M.; Priller, J. Microglia and Brain Macrophages in the Molecular Age: From Origin to Neuropsychiatric Disease. Nat. Rev. Neurosci. 2014, 15, 300-312. [CrossRef] [PubMed]

187. Malm, T.M.; Koistinaho, M.; Pärepalo, M.; Vatanen, T.; Ooka, A.; Karlsson, S.; Koistinaho, J. Bone-Marrow-Derived Cells Contribute to the Recruitment of Microglial Cells in Response to $\beta$-Amyloid Deposition in APP/PS1 Double Transgenic Alzheimer Mice. Neurobiol. Dis. 2005, 18, 134-142. [CrossRef] [PubMed]

188. Simard, A.R.; Soulet, D.; Gowing, G.; Julien, J.-P.; Rivest, S. Bone Marrow-Derived Microglia Play a Critical Role in Restricting Senile Plaque Formation in Alzheimer's Disease. Neuron 2006, 49, 489-502. [CrossRef]

189. Mildner, A.; Schmidt, H.; Nitsche, M.; Merkler, D.; Hanisch, U.-K.; Mack, M.; Heikenwalder, M.; Brück, W.; Priller, J.; Prinz, M. Microglia in the Adult Brain Arise from Ly-6ChiCCR2+ Monocytes Only under Defined Host Conditions. Nat. Neurosci. 2007, 10, 1544-1553. [CrossRef] [PubMed]

190. Mildner, A.; Schlevogt, B.; Kierdorf, K.; Böttcher, C.; Erny, D.; Kummer, M.P.; Quinn, M.; Brück, W.; Bechmann, I.; Heneka, M.T.; et al. Distinct and Non-Redundant Roles of Microglia and Myeloid Subsets in Mouse Models of Alzheimer's Disease. J. Neurosci. 2011, 31, 11159-11171. [CrossRef]

191. Morganti, J.M.; Jopson, T.D.; Liu, S.; Gupta, N.; Rosi, S. Cranial Irradiation Alters the Brain's Microenvironment and Permits CCR2+ Macrophage Infiltration. PLoS ONE 2014, 9, e93650. [CrossRef]

192. Varvel, N.H.; Grathwohl, S.A.; Degenhardt, K.; Resch, C.; Bosch, A.; Jucker, M.; Neher, J.J. Replacement of Brain-Resident Myeloid Cells Does Not Alter Cerebral Amyloid- $\beta$ Deposition in Mouse Models of Alzheimer's Disease. J. Exp. Med. 2015, 212, 1803-1809. [CrossRef]

193. Wang, Y.; Ulland, T.K.; Ulrich, J.D.; Song, W.; Tzaferis, J.A.; Hole, J.T.; Yuan, P.; Mahan, T.E.; Shi, Y.; Gilfillan, S.; et al. TREM2Mediated Early Microglial Response Limits Diffusion and Toxicity of Amyloid Plaques. J. Exp. Med. 2016, 213, 667-675. [CrossRef]

194. Reed-Geaghan, E.G.; Croxford, A.L.; Becher, B.; Landreth, G.E. Plaque-Associated Myeloid Cells Derive from Resident Microglia in an Alzheimer's Disease Model. J. Exp. Med. 2020, 217. [CrossRef]

195. Deming, Y.; Filipello, F.; Cignarella, F.; Cantoni, C.; Hsu, S.; Mikesell, R.; Li, Z.; Del-Aguila, J.L.; Dube, U.; Farias, F.G.; et al. The MS4A Gene Cluster Is a Key Modulator of Soluble TREM2 and Alzheimer's Disease Risk. Sci. Transl. Med. 2019, 11. [CrossRef] [PubMed]

196. Deming, Y.; Filipello, F.; Cignarella, F.; Suárez-Calvet, M.; Morenas-Rodríguez, E.; Hulle, C.A.V.; Jonaitis, E.M.; Blennow, K.; Zetterberg, H.; Asthana, S.; et al. Protective Genetic Variants in the MS4A Gene Cluster Modulate Microglial Activity. Alzheimer's Dement. 2020, 16, e039431. [CrossRef] 
197. Mrdjen, D.; Pavlovic, A.; Hartmann, F.J; Schreiner, B.; Utz, S.G.; Leung, B.P.; Lelios, I.; Heppner, F.L.; Kipnis, J.; Merkler, D.; et al. High-Dimensional Single-Cell Mapping of Central Nervous System Immune Cells Reveals Distinct Myeloid Subsets in Health, Aging, and Disease. Immunity 2018, 48, 380-395. [CrossRef] [PubMed]

198. Goldmann, T.; Jordão, M.J.C.; Wieghofer, P.; Prutek, F.; Hagemeyer, N.; Frenzel, K.; Staszewski, O.; Kierdorf, K.; Amann, L.; Krueger, M.; et al. Origin, Fate and Dynamics of Macrophages at CNS Interfaces. Nat. Immunol. 2016, 17, 797-805. [CrossRef] [PubMed]

199. Hagemeyer, N.; Kierdorf, K.; Frenzel, K.; Xue, J.; Ringelhan, M.; Abdullah, Z.; Godin, I.; Wieghofer, P.; Costa Jordão, M.J.; Ulas, T.; et al. Transcriptome-Based Profiling of Yolk Sac-Derived Macrophages Reveals a Role for Irf8 in Macrophage Maturation. EMBO J. 2016, 35, 1730-1744. [CrossRef] [PubMed]

200. Wang, H.; Morse, H.C. IRF8 Regulates Myeloid and B Lymphoid Lineage Diversification. Immunol. Res. 2009, 43, 109-117. [CrossRef]

201. Louveau, A.; Herz, J.; Alme, M.N.; Salvador, A.F.; Dong, M.Q.; Viar, K.E.; Herod, S.G.; Knopp, J.; Setliff, J.C.; Lupi, A.L.; et al. CNS Lymphatic Drainage and Neuroinflammation Are Regulated by Meningeal Lymphatic Vasculature. Nat. Neurosci. 2018, 21, 1380-1391. [CrossRef]

202. Da Mesquita, S.; Louveau, A.; Vaccari, A.; Smirnov, I.; Cornelison, R.C.; Kingsmore, K.M.; Contarino, C.; Onengut-Gumuscu, S.; Farber, E.; Raper, D.; et al. Functional Aspects of Meningeal Lymphatics in Ageing and Alzheimer's Disease. Nature 2018, 560, 185-191. [CrossRef]

203. Shi, J.; Hua, L.; Harmer, D.; Li, P.; Ren, G. Cre Driver Mice Targeting Macrophages. Methods Mol. Biol 2018, 1784, $263-275$. [CrossRef] [PubMed]

204. Orthgiess, J.; Gericke, M.; Immig, K.; Schulz, A.; Hirrlinger, J.; Bechmann, I.; Eilers, J. Neurons Exhibit Lyz2 Promoter Activity in Vivo: Implications for Using LysM-Cre Mice in Myeloid Cell Research. Eur. J. Immunol. 2016, 46, 1529-1532. [CrossRef] [PubMed]

205. Ayata, P.; Badimon, A.; Strasburger, H.J.; Duff, M.K.; Montgomery, S.E.; Loh, Y.-H.E.; Ebert, A.; Pimenova, A.A.; Ramirez, B.R.; Chan, A.T.; et al. Epigenetic Regulation of Brain Region-Specific Microglia Clearance Activity. Nat. Neurosci. 2018, 21, 1049-1060. [CrossRef] [PubMed]

206. Yona, S.; Kim, K.-W.; Wolf, Y.; Mildner, A.; Varol, D.; Breker, M.; Strauss-Ayali, D.; Viukov, S.; Guilliams, M.; Misharin, A.; et al. Fate Mapping Reveals Origins and Dynamics of Monocytes and Tissue Macrophages under Homeostasis. Immunity 2013, 38, 79-91. [CrossRef] [PubMed]

207. Goldmann, T.; Wieghofer, P.; Müller, P.F.; Wolf, Y.; Varol, D.; Yona, S.; Brendecke, S.M.; Kierdorf, K.; Staszewski, O.; Datta, M.; et al. A New Type of Microglia Gene Targeting Shows TAK1 to Be Pivotal in CNS Autoimmune Inflammation. Nat. Neurosci. 2013, 16, 1618-1626. [CrossRef] [PubMed]

208. Kaiser, T.; Feng, G. Tmem119-EGFP and Tmem119-CreERT2 Transgenic Mice for Labeling and Manipulating Microglia. eNeuro 2019, 6. [CrossRef]

209. Ruan, C.; Sun, L.; Kroshilina, A.; Beckers, L.; De Jager, P.; Bradshaw, E.M.; Hasson, S.A.; Yang, G.; Elyaman, W. A Novel Tmem119-TdTomato Reporter Mouse Model for Studying Microglia in the Central Nervous System. Brain Behav. Immun. 2020, 83, 180-191. [CrossRef]

210. Kim, J.-S.; Kolesnikov, M.; Peled-Hajaj, S.; Scheyltjens, I.; Xia, Y.; Trzebanski, S.; Haimon, Z.; Shemer, A.; Lubart, A.; Van Hove, H.; et al. A Binary Cre Transgenic Approach Dissects Microglia and CNS Border-Associated Macrophages. Immunity 2021, 54, 176-190. [CrossRef]

211. Waisman, A.; Ginhoux, F.; Greter, M.; Bruttger, J. Homeostasis of Microglia in the Adult Brain: Review of Novel Microglia Depletion Systems. Trends Immunol. 2015, 36, 625-636. [CrossRef]

212. Rubino, S.J.; Mayo, L.; Wimmer, I.; Siedler, V.; Brunner, F.; Hametner, S.; Madi, A.; Lanser, A.; Moreira, T.; Donnelly, D.; et al. Acute Microglia Ablation Induces Neurodegeneration in the Somatosensory System. Nat. Commun. 2018, 9, 4578. [CrossRef]

213. Spangenberg, E.E.; Lee, R.J.; Najafi, A.R.; Rice, R.A.; Elmore, M.R.P.; Blurton-Jones, M.; West, B.L.; Green, K.N. Eliminating Microglia in Alzheimer's Mice Prevents Neuronal Loss without Modulating Amyloid- $\beta$ Pathology. Brain 2016, 139, $1265-1281$. [CrossRef]

214. Zhan, L.; Fan, L.; Kodama, L.; Sohn, P.D.; Wong, M.Y.; Mousa, G.A.; Zhou, Y.; Li, Y.; Gan, L. A MAC2-Positive Progenitor-like Microglial Population Is Resistant to CSF1R Inhibition in Adult Mouse Brain. eLife 2020, 9, e51796. [CrossRef]

215. Elmore, M.R.P.; Lee, R.J.; West, B.L.; Green, K.N. Characterizing Newly Repopulated Microglia in the Adult Mouse: Impacts on Animal Behavior, Cell Morphology, and Neuroinflammation. PLoS ONE 2015, 10, e0122912. [CrossRef] [PubMed]

216. Lund, H.; Pieber, M.; Parsa, R.; Han, J.; Grommisch, D.; Ewing, E.; Kular, L.; Needhamsen, M.; Espinosa, A.; Nilsson, E.; et al. Competitive Repopulation of an Empty Microglial Niche Yields Functionally Distinct Subsets of Microglia-like Cells. Nat. Commun. 2018, 9, 4845. [CrossRef] [PubMed]

217. Shemer, A.; Grozovski, J.; Tay, T.L.; Tao, J.; Volaski, A.; Süß, P.; Ardura-Fabregat, A.; Gross-Vered, M.; Kim, J.-S.; David, E.; et al Engrafted Parenchymal Brain Macrophages Differ from Microglia in Transcriptome, Chromatin Landscape and Response to Challenge. Nat. Commun. 2018, 9, 5206. [CrossRef] [PubMed]

218. Nelson, L.H.; Lenz, K.M. Microglia Depletion in Early Life Programs Persistent Changes in Social, Mood-Related, and Locomotor Behavior in Male and Female Rats. Behav. Brain Res. 2017, 316, 279-293. [CrossRef] [PubMed] 
219. Rosin, J.M.; Vora, S.R.; Kurrasch, D.M. Depletion of Embryonic Microglia Using the CSF1R Inhibitor PLX5622 Has Adverse SexSpecific Effects on Mice, Including Accelerated Weight Gain, Hyperactivity and Anxiolytic-like Behaviour. Brain Behav. Immun. 2018, 73, 682-697. [CrossRef] [PubMed]

220. Sosna, J.; Philipp, S.; Albay, R.; Reyes-Ruiz, J.M.; Baglietto-Vargas, D.; LaFerla, F.M.; Glabe, C.G. Early Long-Term Administration of the CSF1R Inhibitor PLX3397 Ablates Microglia and Reduces Accumulation of Intraneuronal Amyloid, Neuritic Plaque Deposition and Pre-Fibrillar Oligomers in 5XFAD Mouse Model of Alzheimer's Disease. Mol. Neurodegener. $2018,13,11$. [CrossRef] [PubMed]

221. Rice, R.A.; Pham, J.; Lee, R.J.; Najafi, A.R.; West, B.L.; Green, K.N. Microglial Repopulation Resolves Inflammation and Promotes Brain Recovery after Injury. Glia 2017, 65, 931-944. [CrossRef]

222. Lei, F.; Cui, N.; Zhou, C.; Chodosh, J.; Vavvas, D.G.; Paschalis, E.I. CSF1R Inhibition by a Small-Molecule Inhibitor Is Not Microglia Specific; Affecting Hematopoiesis and the Function of Macrophages. Proc. Natl. Acad. Sci. USA 2020, 117, 23336-23338. [CrossRef] [PubMed]

223. Han, J.; Fan, Y.; Zhou, K.; Zhu, K.; Blomgren, K.; Lund, H.; Zhang, X.-M.; Harris, R.A. Underestimated Peripheral Effects Following Pharmacological and Conditional Genetic Microglial Depletion. Int. J. Mol. Sci. 2020, 21. [CrossRef]

224. Pyonteck, S.M.; Akkari, L.; Schuhmacher, A.J.; Bowman, R.L.; Sevenich, L.; Quail, D.F.; Olson, O.C.; Quick, M.L.; Huse, J.T.; Teijeiro, V.; et al. CSF-1R Inhibition Alters Macrophage Polarization and Blocks Glioma Progression. Nat. Med. 2013, 19, 1264-1272. [CrossRef]

225. Olmos-Alonso, A.; Schetters, S.T.T.; Sri, S.; Askew, K.; Mancuso, R.; Vargas-Caballero, M.; Holscher, C.; Perry, V.H.; Gomez-Nicola, D. Pharmacological Targeting of CSF1R Inhibits Microglial Proliferation and Prevents the Progression of Alzheimer's-like Pathology. Brain 2016, 139, 891-907. [CrossRef]

226. Schlepckow, K.; Monroe, K.M.; Kleinberger, G.; Cantuti-Castelvetri, L.; Parhizkar, S.; Xia, D.; Willem, M.; Werner, G.; Pettkus, N.; Brunner, B.; et al. Enhancing Protective Microglial Activities with a Dual Function TREM2 Antibody to the Stalk Region. EMBO Mol. Med. 2020, 12, e11227. [CrossRef] [PubMed]

227. Fassler, M.; Rappaport, M.S.; Cuño, C.B.; George, J. Engagement of TREM2 by a Novel Monoclonal Antibody Induces Activation of Microglia and Improves Cognitive Function in Alzheimer's Disease Models. J. Neuroinflamm. 2021, 18, 19. [CrossRef] [PubMed]

228. Song, W.M.; Joshita, S.; Zhou, Y.; Ulland, T.K.; Gilfillan, S.; Colonna, M. Humanized TREM2 Mice Reveal Microglia-Intrinsic and -Extrinsic Effects of R47H Polymorphism. J. Exp. Med. 2018, 215, 745-760. [CrossRef] [PubMed]

229. Evans, R.M.; Mangelsdorf, D.J. Nuclear Receptors, RXR \& the Big Bang. Cell 2014, 157, 255-266. [CrossRef] [PubMed]

230. Mandrekar-Colucci, S.; Karlo, J.C.; Landreth, G.E. Mechanisms Underlying the Rapid Peroxisome Proliferator-Activated Receptor$\gamma$-Mediated Amyloid Clearance and Reversal of Cognitive Deficits in a Murine Model of Alzheimer's Disease. J. Neurosci. 2012, 32, 10117-10128. [CrossRef] [PubMed]

231. Skerrett, R.; Pellegrino, M.P.; Casali, B.T.; Taraboanta, L.; Landreth, G.E. Combined Liver X Receptor/Peroxisome ProliferatorActivated Receptor $\gamma$ Agonist Treatment Reduces Amyloid $\beta$ Levels and Improves Behavior in Amyloid Precursor Protein/Presenilin 1 Mice. J. Biol. Chem. 2015, 290, 21591-21602. [CrossRef]

232. Cramer, P.E.; Cirrito, J.R.; Wesson, D.W.; Lee, C.Y.; Karlo, J.C.; Zinn, A.E.; Casali, B.T.; Restivo, J.L.; Goebel, W.D.; James, M.J.; et al. ApoE-Directed Therapeutics Rapidly Clear Beta-Amyloid and Reverse Deficits in AD Mouse Models. Science 2012, 335, $1503-1506$. [CrossRef]

233. Casali, B.T.; Corona, A.W.; Mariani, M.M.; Karlo, J.C.; Ghosal, K.; Landreth, G.E. Omega-3 Fatty Acids Augment the Actions of Nuclear Receptor Agonists in a Mouse Model of Alzheimer's Disease. J. Neurosci. 2015, 35, 9173-9181. [CrossRef]

234. Malm, T.; Mariani, M.; Donovan, L.J.; Neilson, L.; Landreth, G.E. Activation of the Nuclear Receptor PPAR $\delta$ Is Neuroprotective in a Transgenic Mouse Model of Alzheimer's Disease through Inhibition of Inflammation. J. Neuroinflamm. 2015, 12. [CrossRef] [PubMed]

235. Lefterov, I.; Schug, J.; Mounier, A.; Nam, K.N.; Fitz, N.F.; Koldamova, R. RNA-Sequencing Reveals Transcriptional up-Regulation of Trem2 in Response to Bexarotene Treatment. Neurobiol. Dis. 2015, 82, 132-140. [CrossRef] [PubMed]

236. Mariani, M.M.; Malm, T.; Lamb, R.; Jay, T.R.; Neilson, L.; Casali, B.; Medarametla, L.; Landreth, G.E. Neuronally-Directed Effects of RXR Activation in a Mouse Model of Alzheimer's Disease. Sci. Rep. 2017, 7, 42270. [CrossRef]

237. Mounier, A.; Georgiev, D.; Nam, K.N.; Fitz, N.F.; Castranio, E.L.; Wolfe, C.M.; Cronican, A.A.; Schug, J.; Lefterov, I.; Koldamova, R. Bexarotene-Activated Retinoid X Receptors Regulate Neuronal Differentiation and Dendritic Complexity. J. Neurosci. 2015, 35, 11862-11876. [CrossRef]

238. Saijo, K.; Crotti, A.; Glass, C.K. Regulation of Microglia Activation and Deactivation by Nuclear Receptors. Glia 2013, 61, 104-111. [CrossRef]

239. Gao, T.; Jernigan, J.; Raza, S.A.; Dammer, E.B.; Xiao, H.; Seyfried, N.T.; Levey, A.I.; Rangaraju, S. Transcriptional Regulation of Homeostatic and Disease-Associated-Microglial Genes by IRF1, LXR $\beta$ and CEBP $\alpha$. Glia 2019, 67, 1958-1975. [CrossRef] [PubMed]

240. Morikawa, M.; Fryer, J.D.; Sullivan, P.M.; Christopher, E.A.; Wahrle, S.E.; DeMattos, R.B.; O’Dell, M.A.; Fagan, A.M.; Lashuel, H.A.; Walz, T.; et al. Production and Characterization of Astrocyte-Derived Human Apolipoprotein E Isoforms from Immortalized Astrocytes and Their Interactions with Amyloid-Beta. Neurobiol. Dis. 2005, 19, 66-76. [CrossRef] 